\title{
Seasonal and short-time-scale dynamics of microplankton community production and respiration in an inshore upwelling system
}

\author{
Gwenaëlle Moncoiffée ${ }^{1, *}$, Xosé Antón Alvarez-Salgado², Francisco G. Figueiras ${ }^{2}$, \\ Graham Savidge ${ }^{1}$
}

'Queen's University of Belfast Marine Laboratory, School of Biology and Biochemistry, Dept. of Environmental Sciences, Portaferry, BT22 1PF County Down, Northern Ireland, UK

${ }^{2}$ Instituto de Investigacions Mariñas, CSIC, Eduardo Cabello 6, 36208 Vigo, Spain

\begin{abstract}
An intensive study of pelagic primary production and microplankton community respiration was carried out during an entire upwelling season in the Ria de Vigo (NW Spain). From April to November measurements of oxygen production and respiration using the light-dark bottle technique were made twice a week at the surface, $1 \%$ light depth $(1 \% L D, 12 \pm 4 \mathrm{~m})$ and $40 \mathrm{~m}(8 \mathrm{~m}$ above sea floor) alongside routine physical, chemical and biological measurements. During the major part of the survey period intermittent intrusions of cold, nutrient-rich upwelled water were observed in the ria with a periodicity of about 2 wk. Rates of gross primary production (GPP) were high but variable averaging $37.3 \pm 30.7 \mu \mathrm{M} \mathrm{O}_{2} \mathrm{~d}^{-1}$ and $3.6 \pm 4.8 \mu \mathrm{M} \mathrm{O}_{2} \mathrm{~d}^{-1}$ at the surface and $1 \% \mathrm{LD}$ respectively over the period of survey $(n=50)$. Rates of dark community respiration (DCR) were also high and variable with maximum values being observed in the surface layer where the seasonal average was $12.2 \pm 9.8 \mu \mathrm{MO}$ $\mathrm{d}^{-1}$. At the $1 \% \mathrm{LD}$ and $40 \mathrm{~m}, \mathrm{DCR}$ averaged $5.3 \pm 4.4$ and $2.8 \pm 3.0 \mu \mathrm{M} \mathrm{O}_{2} \mathrm{~d}^{-1}$ respectively. Although seasonal average and maximal DCR (up to $46.5 \mu \mathrm{M} \mathrm{O}_{2} \mathrm{~d}^{-1}$ ) were among the highest reported for coastal areas, microplankton production over the period of survey was dominated by autotrophic processes. Respiration losses by the microplankton community in the euphotic zone represented on average $43 \%$ of estimated mean seasonal water column GPP $\left(2.1\right.$ to $\left.2.7 \mathrm{~g} \mathrm{C} \mathrm{m}^{-2} \mathrm{~d}^{-1}\right)$. Net heterotrophy in the aphotic layer consumed the equivalent of a further $25 \%$ of estimated water column GPP. The degree of coupling between primary production and respiration was primarily controlled by upwelling. During upwelling events respiration was generally low in the water column but it increased as a linear function of chlorophyll a concentration $\left(R^{2}=0.55, n=13\right)$ and $G P P\left(R^{2}=0.47, n=13\right)$ in the surface layer. Under such condition phytoplankton appears as the dominant component of community respiration consuming $14 \%$ of GPP. During periods of upwelling relaxation respiration was high relative to GPP. High water column respiration rates extending occasionally down to $40 \mathrm{~m}$ took place at the expense of organic matter trapped inside the bay. The seasonal breakdown of thermal stratification in autumn presented a relationship between surface respiration and chlorophyll a or GPP similar to that observed during upwelling events. The large excess primary production during this period was not remineralised inside the ria, suggesting that a large fraction may be exported towards the shelf
\end{abstract}

KEY WORDS: Primary production - Respiration · Oxygen - Iberian Upwelling System - NE Atlantic

\section{INTRODUCTION}

Primary production and respiration are the 2 fundamental biological processes driving the fluxes of organic

\footnotetext{
- Present address: British Oceanographic Data Centre, Centre for Coastal and Marine Sciences, Proudman Oceanographic Laboratory, Bidston Observatory, Prenton CH43 7RA, United Kingdom. E-mail: gmon@pol.ac.uk
}

matter in marine ecosytems and their ratio is an important ecological index which defines the trophic status of biological communities. In marine pelagic systems with limited external inputs of organic matter, phytoplankton primary production is the principal source of organic carbon and the balance between the 2 processes defines the amount of organic matter available for export from a given system (Quinones \& Platt 1991). However the degree of coupling between production 
and community respiration is subject to a number of physical and biological interactions which cause the 2 processes to be separated in time and space (Williams 1984, Smith \& Kemp 1995). While measurements of primary production have been carried out routinely in the marine environment for several decades (Peterson 1980 ), it is only comparatively recently that sufficiently precise and automated methods for oxygen determination have made intensive measurements of respiration rates possible (Kuparinen 1987, Kenney et al. 1988, Jensen et al. 1990, Griffith et al. 1990, Kemp et al. 1992, Blight et al. 1995). For this reason, the factors controlling the seasonal and short-term balance between primary production and respiration processes in marine pelagic systems are still poorly understood (Sherr \& Sherr 1996, del Giorgio et al. 1997, Geider 1997).

The Rias Baixas are 4 coastal indentations along the NW coast of the Iberian Peninsula, an area of active upwelling located at the northern boundary of the NW African upwelling system. These embayments function as partially stratified estuaries (Bowden 1980). During the upwelling season from April to September, runoff and river discharge are at their seasonal minimum (Nogueira et al. 1997), and the 2-layer circulation is largely controlled by the fluctuations of wind-driven upwelling processes on the sheif (Rosón et al. 1995, Alvarez-Salgado et al. 1996a). As a consequence, during the upwelling season, the Rias Baixas can be considered as an extension of the shelf. During periods of low wind stress, the exchange rate between the rias and the ocean is minimum (Alvarez-Salgado et al. 1996b) and the slow residual circulation pattern allows for the development of a strong thermal stratification (Nogueira et al. 1997). Intensification of the dominant northerly winds drives surface water away from the coast inducing the upwelling of Eastern North Atlantic Central Water (ENACW) onto the shelf (Fraga 1981, Ríos et al. 1992b, Pérez et al. 1995). This circulation pattern enhances the 2-layer positive circulation and results in the inflow and upwelling of cold and nitraterich ENACW inside the rias. Conversely, the immediate relaxation of upwelling-favourable winds or the onset of downwelling-favourable winds causes ENACW to withdraw to deeper depths and oceanic surface waters to move towards the coast. This results in the formation of a convergence front along the coast (Blanton et al. 1984, Castro et al. 1994). Its location on the shelf will depend on the balance between river discharge and wind stress. Hence, under conditions of strong southerly winds, a downwelling front is observed inside the rias (Tilstone et al. 1994, Alvarez-Salgado et al. 1996b, Fermín et al. 1996). During a typical year, strong downwelling-favourable winds are mainly observed at the end of the upwelling season in autumn while succession of upwelling stress-relaxation cycles with a 2 wk frequency is the normal pattern during spring and summer. The resulting situation whereby cycles of stratification-destratification are superimposed on a marked seasonal cycle makes the Rias Baixas an ideal site for studying the coupling between physical and biological processes.

The fertilisation of the rias by upwelling processes leads to their high productivity. The overall control of the hydrodynamic regime on biological activity inside the rias has been particularly well studied with regards to phytoplankton succession (Figueiras \& Pazos 1991, Figueiras \& Ríos 1993), bacterial abundance (Zdanowski \& Figueiras 1997), mussel secondary production (Tenore et al. 1982, Blanton et al. 1987) and certain aspects of biogeochemical cycles in the rias (Prego 1993, 1994, Alvarez-Salgado et al. 1996a,b). On a larger scale, the influence of the high productivity of the Galician Rias extends to the nearby Atlantic shelf, where part of the high biomass produced in the rias is exported and remineralised (Alvarez-Salgado et al. 1997, Prego \& Bao 1997) leaving a distinct signature on the distribution of the chemical (Fraga 1981, Alvarez-Salgado et al. 1993) and biological (Estrada 1984) characteristics of the open shelf waters.

In this study we report the results of an intensive measurement series of pelagic community oxygen production and respiration rates carried out during an entire upwelling season at a time-series station in the Ria de Vigo, the southernmost of the 4 Rias Baixas. The experimental work was superimposed on an on-going long-term monitoring of the basic hydrographic properties at this station since 1987 (Nogueira et al. 1997). Annual cycles of primary production have been studied on 2 occasions in the Ria de Vigo either based on carbon-14 uptake (Fraga 1976) or using a 2-dimensional steady-state box model (Prego 1993). Both studies however were based on sampling frequencies greater than $1 \mathrm{mo}$, which would not be representative of the expected hydrographic variability. The sampling frequency of twice a week used in the present study allows us to resolve the short-time-scale dynamics of primary production during the upwelling season. This study is to our knowledge the first to address both the seasonal and the short-time-scale coupling of microplankton primary production and respiration in a coastal upwelling system.

\section{MATERIAL AND METHODS}

Sampling and hydrographic data. Sampling was carried out twice a week (between 09:00 and 10:30 h local time) from 15 April to 11 November 1991 at a timeseries station (TSS: $42^{\circ} 14.5^{\prime} \mathrm{N}, 8^{\circ} 45.5^{\prime} \mathrm{W}$; Fig. 1 ) over the central channel of the Ria de Vigo ( $48 \mathrm{~m}$ deep). 


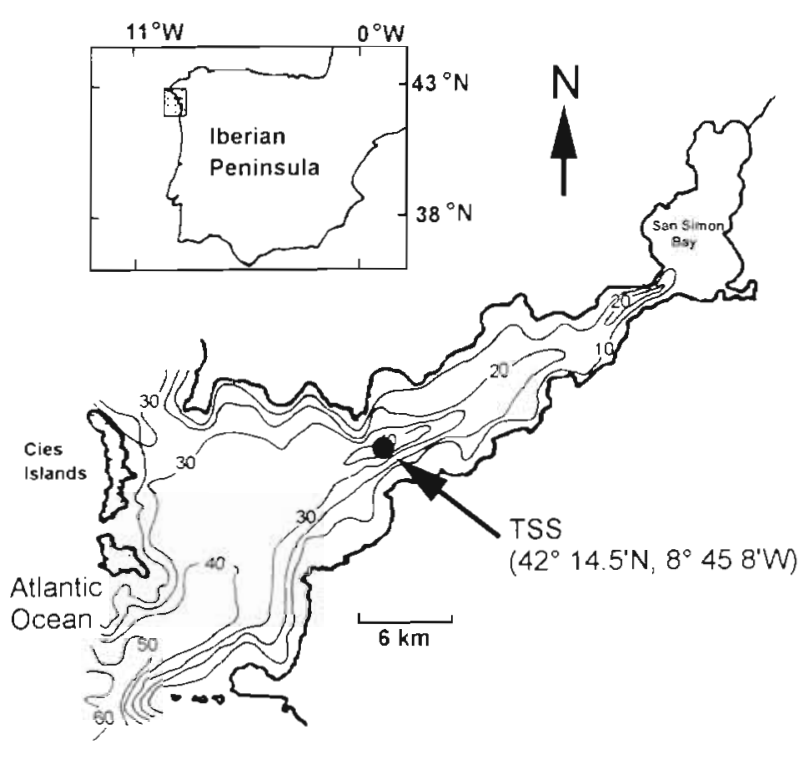

Fig. 1. Map and bathymetry $(\mathrm{m})$ of the Ria de Vigo showing location of the study area on the NW coast of the Iberian Peninsula and position of the time-series station (TSS) in the ria

Samples were collected from the small research boat 'Lampadena' of the Instituto de Investigacions Mariñas with 51 PVC Niskin bottles equipped with rotating thermometer frames. Three depths were sampled: surface, $1 \%$ light depth ( $1 \%$ LD) determined by a LICOR underwater quantum sensor, and $40 \mathrm{~m}(8 \mathrm{~m}$ above the sea floor). Salinity was calculated from Eq. (6) in UNESCO (1981) from conductivity measurements made with an AUTOSAL 8400A salinometer. Density anomaly was calculated from Eq. (9) in UNESCO (1986). Aliquots for nutrient determination were frozen at $-20^{\circ} \mathrm{C}$ after sampling and analysed by a Technicon AAII segmented-flow-analysis system (Hansen \& Grasshoff 1983) with some modifications (Mouriño \& Fraga 1985, Alvarez-Salgado et al. 1992). In situ chlorophyll a (chl a) concentration was determined after filtration through Whatman GF/F filters by the fluorometric method (Yentsch \& Menzel 1963) using a Turner Designs $10000 \mathrm{R}$ fluorometer. The values were not corrected for phaeopigment content.

Upwelling index and runoff. Offshore upwelling indices (Iw) at $43^{\circ} \mathrm{N}, 11^{\circ} \mathrm{W}$ were obtained by the Instituto Español de Oceanografía in Vigo and were calculated according to Woodster et al. (1976):

$$
I w=\left(\rho_{a} \cdot C \cdot|V| \cdot V_{N}\right) /\left(f \cdot \rho_{w}\right)
$$

where $\rho_{a}$ is the density of air, $1.22 \mathrm{~kg} \mathrm{~m}^{-3}$ at $15^{\circ} \mathrm{C} ; \mathrm{C}$ is an empirical drag coefficient (dimensionless), $1.3 \times 10^{3}$ according to Hidy $(1972) ;|V|$ is the wind speed; and $V_{N}$ is the north component of wind speed; $f$ is the Coriolis parameter, $9.946 \times 10^{-5} \mathrm{~s}^{-1}$ at $43^{\circ}$ latitude; $\rho_{w}$ is the density of water, $1025 \mathrm{~kg} \mathrm{~m}^{-3}$. Daily averages of geo- strophic wind velocity at $43^{\circ} \mathrm{N}, 11^{\circ} \mathrm{W}$ (Stn G1) deduced from surface pressure charts were used (Bakun 1973). This index, equivalent to the Ekman transport, provides an estimation of the water flow $\left(\mathrm{m}^{3} \mathrm{~s}^{-1}\right)$ upwelled per $\mathrm{km}$ of shoreline due to wind stress, with negative values indicating downwelling. In the context of our study I w was averaged over the $3 \mathrm{~d}$ prior to sampling (Alvarez-Salgado et al. 1996a). The runoff in the drainage basin up to the TSS was calculated as a function of precipitation according to Rios et al. (1992a).

Production and respiration rates. Daily photosynthetic and respiration rates of the microplankton community were estimated with the oxygen light-dark bottle method (Strickland \& Parsons 1972). The content of 3 Niskin bottles was collected from each depth and pooled in darkened carboys. From 15 April to 3 September, water samples were prefiltered through $150 \mu \mathrm{m}$ mesh. After 3 September the samples were incubated without prefiltration. Additional experiments with $150 \mu \mathrm{m}$ pre-screened samples carried out once a week during this period showed no significant difference with the whole water samples. The carboys were gently shaken before subsampling to prevent the sedimentation of particulate material. Series of nine $120 \mathrm{ml}$ Winkler bottles composed of triplicate initial, light and dark subsamples were then filled by siphoning. Subsamples for chlorophyll determination were drawn at the end of each series and analysed as above. Following subsampling, initial, light and dark bottles were kept in similar dark and cool conditions, immersed in sea water, until the incubation was ready to start (within 2 to $3 \mathrm{~h}$ after sampling). Light and dark bottles were then incubated in situ from a floating line for $24 \mathrm{~h}$. The initial bottles were fixed on board within half an hour of the start of the incubation. Dark and light bottles were fixed 24 h later in similar conditions.

Oxygen titration was performed by a SIS microprocessor-controlled titrator system using the colourimetric Winkler method following modifications by Carrit \& Carpenter (1966). Rates of microplankton net community production (NP), gross primary production (GPP) and dark community respiration (DCR) were calculated from the mean oxygen concentrations of the triplicates initial, light and dark subsamples and expressed in $\mu \mathrm{M} \mathrm{O}_{2} \mathrm{~d}^{-1}$. The detection limit of the method was typically $<2 \mu \mathrm{M} \mathrm{O}_{2} \mathrm{~d}^{-1}$. The precision on oxygen determination among replicates averaged $0.3 \%$ for initial samples and $0.4 \%$ for incubated samples. Anomalies in oxygen production loxygen concentration in 'dark bottles' was significantly higher than in 'light' or 'initial' series; Dugdale \& Wallace 1960) were occasionally observed during the summer in samples from the $1 \% \mathrm{LD}$ and $40 \mathrm{~m}$. Significantly higher oxygen concentration in dark replicates relative to light replicates was observed in $6 \%$ of the 350 
paired light and dark replicates analysed during the study and averaged $3.7 \pm 2.7 \mu \mathrm{M} \mathrm{O}_{2}$. More than half of these anomalies occurred at $40 \mathrm{~m}$ (incubated below the $1 \% \mathrm{LD}$ ), therefore excluding the hypothesis that a light-related mechanism (e.g. light-enhanced microalgal respiration) was responsible. Although the cause of the anomaly has not been clearly identified it was found that the variability among dark replicates in the series sampled from the $1 \% \mathrm{LD}$ and from $40 \mathrm{~m}$ was significantly higher on the dates when anomalies were observed (non-parametric Kolmogorov-Smirnov test, $p<0.01$ ). In contrast samples from the surface layer showed no significant difference, giving reason to believe that oxygen production rates at the surface were not affected. Since on all occasions net oxygen consumption was observed in the 'light' bottle series, respiration rates at $40 \mathrm{~m}$ on the dates with apparent oxygen production in the dark were calculated from the oxygen decrease observed in the 'light' bottle series. A similar correction was applied to the affected series from the $1 \% \operatorname{LD}(n=8)$ although in this case, as significant gross photosynthesis is likely to have taken place, both DCR and GPP are probably underestimated. Observation of trends within the whole timeseries suggested that the underestimation of DCR and GPP at the $1 \%$ LD on those dates was unlikely to have exceeded the detection limit of our technique.

Seasonal average oxygen production was converted to equivalent carbon production using photosynthetic quotients (PQs) of 1.1 and 1.4 rather than assuming a single average $P Q$. This seems appropriate in order to account for the variability in PQs associated with variable nitrogen nutrient sources (Laws 1991, Williams \& Robertson 1991) in a system where both nitrate and ammonium might support a significant fraction of phytoplankton production (Alvarez-Salgado et al. 1996a,b).

\section{RESULTS}

\section{Physico-chemical characterisation of the upwelling-relaxation cycles}

The distribution of off-shore upwelling indices (Iw) in 1991 (Fig. 2a) was characterised by a predominance of upwelling-favourable conditions (as inferred by positive Iw) over the major part of the period of survey. However wind stress was highly variable and periods of strong northerly winds (Iw above $500 \mathrm{~m}^{3} \mathrm{~s}^{-1} \mathrm{~km}^{-1}$ ) alternated with periods of low or negative Iw. As a result, 7 major upwelling-relaxation cycles can be identified between April and September (Fig. 2a). The consequence of coastal upwelling on the hydrography inside the ria can be traced from the evolution of water den- sity anomaly at the time-series station (TSS) (Fig. 2b) Density anomalies greater than 26.9 are characteristic of Eastern North Atlantic Central Water (ENACW) that upwells from 150 to $200 \mathrm{~m}$ over the Galician shelf before being advected alongside the bottom of the bay (Fraga 1981, Alvarez-Salgado et al. 1993). Periods of high positive Iw corresponded with the presence at $40 \mathrm{~m}$ of water with density anomalies greater than 26.9, indicating an inflow of ENACW inside the bay. The subsequent upwelling of ENACW at the level of the TSS is clearly observed for each of the 7 upwellingrelaxation episodes identified in Fig. 2a. Maxima of upwelling forcing inside the bay (marked by an arrow in Fig. 2b) can usually be identified by simultaneous density maxima at the surface and at $40 \mathrm{~m}$ as the deep cold water is advected into the euphotic zone (Fig. 2c). The cessation of upwelling-favourable conditions led to a decrease in bottom water density, indicating the retreat of ENACW from the ria. Prolonged periods of low wind stress were associated with an increase in surface temperature and with the strengthening of the water column stratification (Fig. 2c). Overall, from 15 April to 19 September, 59 and $29 \%$ of the variance of log-transformed gamma-t values at $40 \mathrm{~m}$ and at the surface respectively were accounted for by variations of Iw ( $p<0.001, n=45)$. The relationship was poor after 19 September when high runoff caused by heavy rainfalls became the main forcing agent of estuarine circulation (Fig. 2a). The time-course of nitrate and ammonium concentrations (Fig. 3) also reflected the short-term succession of upwelling-relaxation events in the ria. Inflows of nitrate-rich ENACW fertilised the bay with high concentration of nitrate reaching values

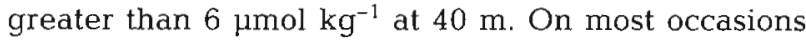
upwelling resulted in marked pulses of high nitrate concentration in the photic layer. Conversely during periods of low wind stress ammonium concentrations typically increased at $40 \mathrm{~m}$ to become the dominant inorganic nitrogen form in the bottom layer. The depth of the $1 \%$ isolume which was taken as the definition of the euphotic zone (Fig. 3c) varied between 5 and $22 \mathrm{~m}$ and averaged $12 \pm 4 \mathrm{~m}$ over the period of survey.

Temporal patterns in the wind regime and the evolution of the seasonal thermal stratification led to the distinction of 4 sub-periods. Period I, defined from 15 April to 31 May, was characterised by persistent upwelling-favourable conditions which maintained nitrate-rich ENACW inside the ria. The water column was initially weakly stratified. Wind intensification resulted in the rapid uplift of ENACW into the euphotic zone on 22 April and 6 to 20 May (Events 1 and 2) and

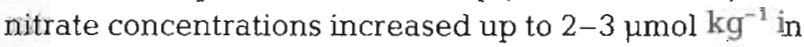
the surface layer. The relaxation of wind stress at the end of the period allowed for the rapid establishment of seasonal thermal stratification with surface tempera- 


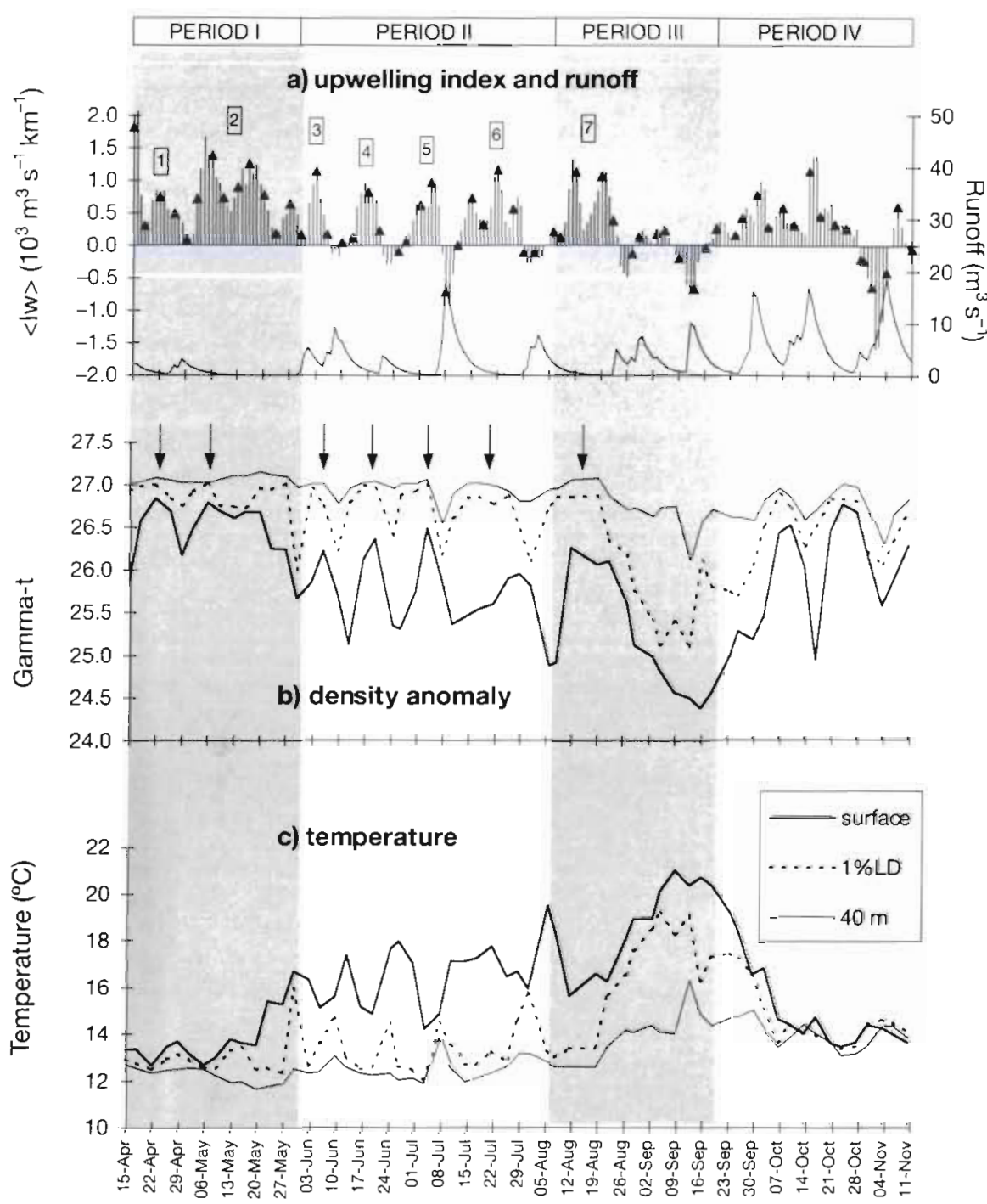

Fig. 2. Time-course from 15 April to 11 November 1991 of (a) 3 d average offshore upwelling index (Iw) calculated from geostrophic wind speeds at $43^{\circ} \mathrm{N}, 11^{\circ} \mathrm{W}$ (I $w_{1} \mathrm{~m}^{3} \mathrm{~s}^{-1} \mathrm{~km}^{-1}$ of coastline) and runoff $\left(\mathrm{m}^{3} \mathrm{~s}^{-1}\right.$ ), (b) density anomaly (gamma-t) at the surface, $1 \%$ light depth (1\% LD) and $40 \mathrm{~m}$, (c) temperature at the surface, $1 \% \mathrm{LD}$ and $40 \mathrm{~m}$. The 4 periods mark arbitrary subdivisions of the upwelling season (see text) into spring (Period I), summer (Period II), late summer (Period III) and autumn (Period IV). Arrows and numbers 1 to 7 locate the upwelling events

completely destroy the thermal stratification. For the strongest events (Events 4 and 5) surface temperature dropped by 2.5 to $3.5^{\circ} \mathrm{C}$ and surface nitrate concentration increased above $2 \mu \mathrm{mol} \mathrm{kg}{ }^{-1}$. The last event of the period (Event 6) was weak and upwelling was only detected in the lower part of the euphotic zone. Relaxation from upwelling led to the outflow of ENACW from the ria and to its replacement by a warmer $\left(13.1\right.$ to $\left.13.9^{\circ} \mathrm{C}\right)$ and nitratepoor ( 2.7 to $3.8 \mu \mathrm{mol} \mathrm{kg}{ }^{-1}$ ) water on 10 June, 8 July and 29 July to 1 August. High thermal stratification was generally re-established a week after cessation of upwelling. The late summer period (Period III) from 8 August to 19 September corresponded to an hydrographic sequence often associated with red tide development in the Rias Baixas (Fraga et al. 1988, 1993, Tilstone et al. 1994, Pazos et al. 1995). A strong upwelling event centred on 12 August was followed by a lasting period of low wind stress from 22 August to 9 September (Fig. 2). Temperature increased at the 3 depths sampled, reaching a seasonal maximum of $21.0^{\circ} \mathrm{C}$ at the surface and $16.3^{\circ} \mathrm{C}$ at $40 \mathrm{~m}$ while a strong temperature gradient developed below the $1 \%$ LD. Nitrate became depleted down to the $1 \% \mathrm{LD}$ (ca $10 \mathrm{~m}$ ) while increases in ammonium concentration were occasionally observed at the surface and at the $1 \%$ LD towards the end of the relaxation period. A remarkable feature of this late summer period was the steady increase in ammonium concentration in the deeper layer from $1.2 \mu \mathrm{mol} \mathrm{kg}{ }^{-1}$ on 12 August to $8.4 \mu \mathrm{mol}$ $\mathrm{kg}^{-1}$ on 9 September. All these observations point to an important decrease

ture increasing from 13 to $17^{\circ} \mathrm{C}$ from 20 to $30 \mathrm{May}$ (Fig. 2c). During Period II, defined from 1 June to 7 August, intermittent relaxation and weak reversal of the dominant upwelling-favourable winds were observed with a periodicity of about $2 \mathrm{wk}$ (Fig. 2a). The alternation in the wind regime resulted in 4 marked upwelling-relaxation events in the ria on 6 June (Event 3), 17 to 20 June (Event 4), 4 July (Event 5) and 18 to 22 July (Event 6). The resulting hydrographic variability contrasted with the spring period. The intensity of the 4 upwelling events was variable although never strong enough to of the exchange rates in the ria. The autumn period (Period IV) from 20 September to 11 November corresponded to the seasonal breakdown of thermal stratification. Weak but persistent northerly winds from 20 September to 27 October contributed again to the uplift of the colder deep water to the surface and to the rapid decrease of thermal stratification from 20 September to 14 October. A water column density gradient was maintained due to the increase in freshwater runoff during this period (Fig. 2a). The time-course of nutrients was characteristic of the autumn-winter tran- 


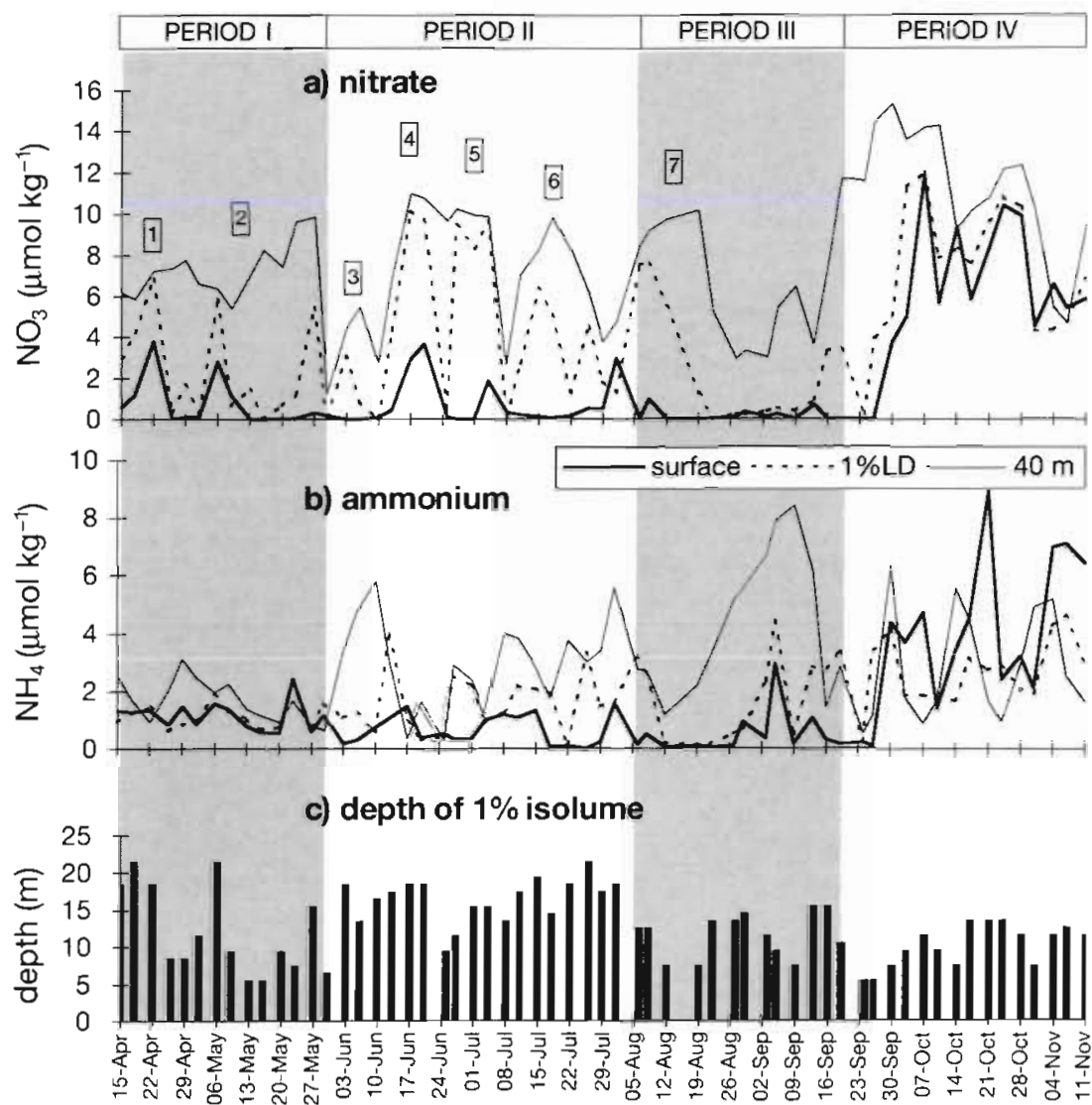

Fig. 3. Time-course from 15 April to 11 November 1991 of (a) nitrate concentration, (b) ammonium concentration at the surface, 1\% LD and $40 \mathrm{~m}$, and (c) depth of the $1 \%$ isolume

sition period of temperate systems with a rapid replenishment of the euphotic zone in nitrate $\left(>3.5 \mu \mathrm{mol} \mathrm{\textrm {kg } ^ { - 1 }}\right.$ from 30 September onwards). Ammonium concentration was also high particularly at the surface $(>1 \mu \mathrm{mol}$ $\mathrm{kg}^{-1}$ ) although more variable with important increases being observed in the entire water column concomitant with periods of high runoff.

\section{Chlorophyll and gross primary production}

Chl a concentration averaged $6.0 \pm 4.2 \mu \mathrm{g} \mathrm{l}^{-1}$ (range: 0.2 to $17.5 \mu \mathrm{g} \mathrm{l}^{-1}$ ) and $4.8 \pm 4.8 \mu \mathrm{g} \mathrm{l}^{-1}$ (range: 0.2 to $22.2 \mathrm{~g}^{-1}$ ) respectively at the surface and at the $1 \% \mathrm{LD}$ over the period of study (Fig. 4). The highest concentrations (>15 $\mathrm{g} \mathrm{l}^{-1}$ ) were observed during 2 lasting blooms in April-May (Period I) and in September (Periods III and IV], and during the late summer upwelling event at the beginning of Period III. All 3 blooms were composed almost exclusively of diatoms and were dominated by small Chaetoceros spp. cells in April-May, a mixed diatom assemblage of small centric diatoms, large Chaetoceros spp. and large centric diatoms in Au- gust, and mainly Skeletonema costatum in autumn. Chl a tended to be lower during the main summer period and, although blooms of minor amplitudes were observed, maximum concentrations remained below $10 \mathrm{ug} \mathrm{l}^{-1}$. At $40 \mathrm{~m}$, chl a was generally low, averaging $2.1 \mathrm{\mu g} \mathrm{l}^{-1}$ (range: 0 to $6.6 \mu \mathrm{g} \mathrm{l}^{-1}$ ). Higher concentrations ( $>4 \mu \mathrm{g} \mathrm{l}^{-1}$ ) were observed following the blooms in April-May and in August and between the 2 upwelling events in July, suggesting that significant sedimentation was taking place in the ria. On the other hand concentrations remained remarkably low in June and during the entire period of the autumn bloom in September.

The evolution of gross oxygen production rates (GPP) in the surface layer (Fig. 5a) exhibited a similar pattern to that of chl a. High GPP (maxima up to 82-123 $\mu \mathrm{M} \mathrm{O}_{2} \mathrm{~d}^{-1}$ ) was measured during the spring and autumn blooms and during the upwelling event in August. It should be noted that, during the spring, the lack of primary production measurement on the 2 dates when chl a was maximum would result in an underestimation of GPP during this period. During the main summer period GPP was lower (Table 1) with values ranging from $<2$ to $58 \mu \mathrm{M} \mathrm{O}_{2} \mathrm{~d}^{-1}$.

The relationship between GPP and chl $a$ at the surface was highly significant (Table 2). The relatively high value calculated for the slope (equivalent

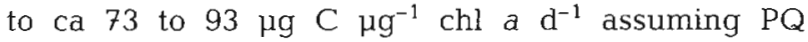
values of 1.1 to 1.4 ) indicated that the phytoplankton populations sampled were generally healthy although the poor significance of the intercept indicated that substantial variability existed at low biomass. Overall such relationship suggests that a large proportion of the variability of chl a concentration was controlled by in situ growth. One outlying point (excluded from the regression line calculation) corresponded to the sample of 9 September when high chl a $\left(12 \mu \mathrm{g} \mathrm{l}^{-1}\right)$ was associated with low GPP $(23.5 \mu \mathrm{M}$ $\mathrm{O}_{2} \quad \mathrm{~d}^{-1}$ ). Between 5 and 9 September a sudden change of phytoplankton community from a dinoflagellate- to a diatom-dominated community was observed (Figueiras unpubl.). The dominant diatom species Skeletonema costatum was unrecorded at the 2 photic depths sampled 4 d before suggesting that the high biomass recorded at the TSS on 9 September was proceeding from the advection of a senescent bloom. 


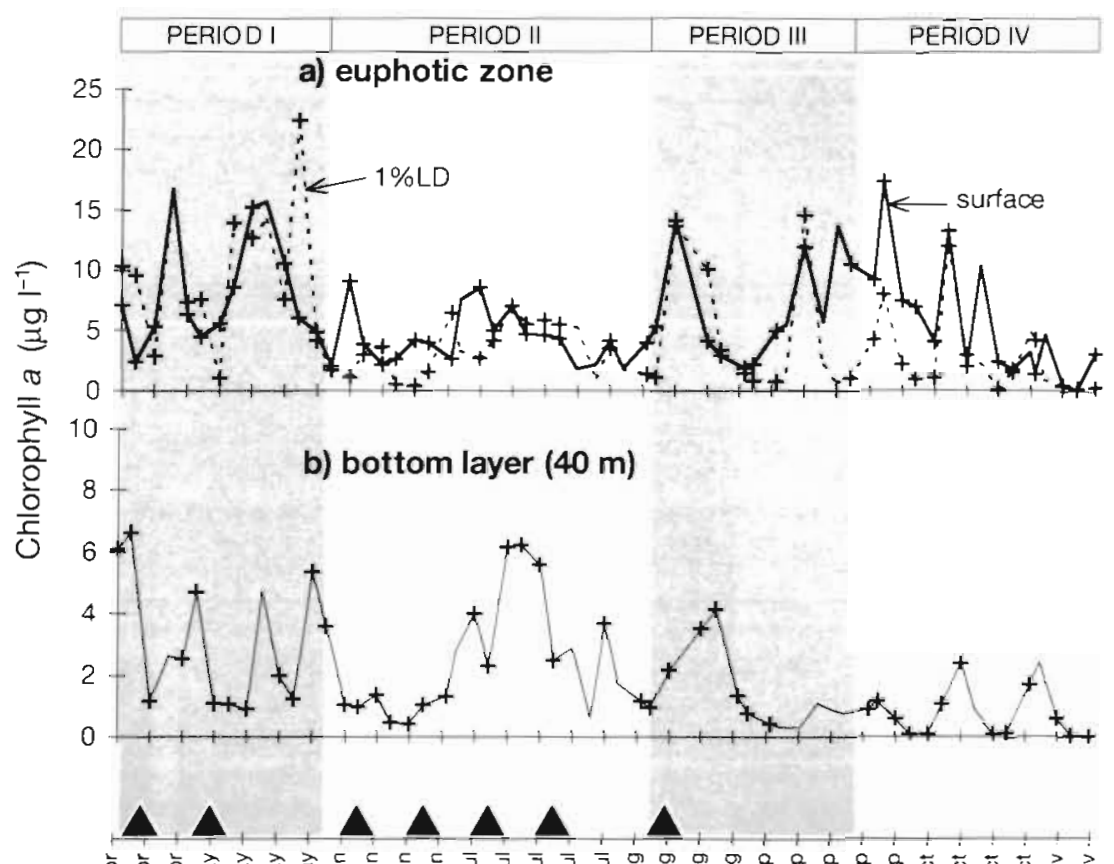

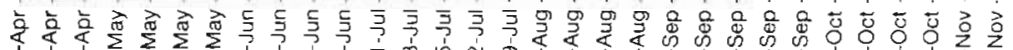

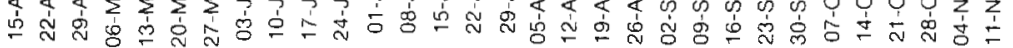

Fig. 4. Time-course from 15 April to 11 November 1991 of chlorophyll concentration at (a) the surface and $1 \% \mathrm{LD}$ and (b) $40 \mathrm{~m}$. Symbols indicate sampling dates with oxygen production experiments. Arrows on the date axis locate the upwelling events

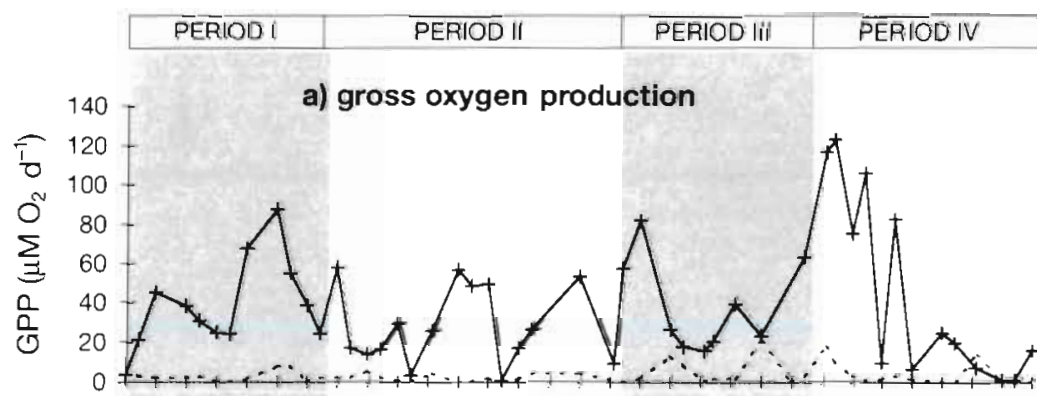

b) respiration

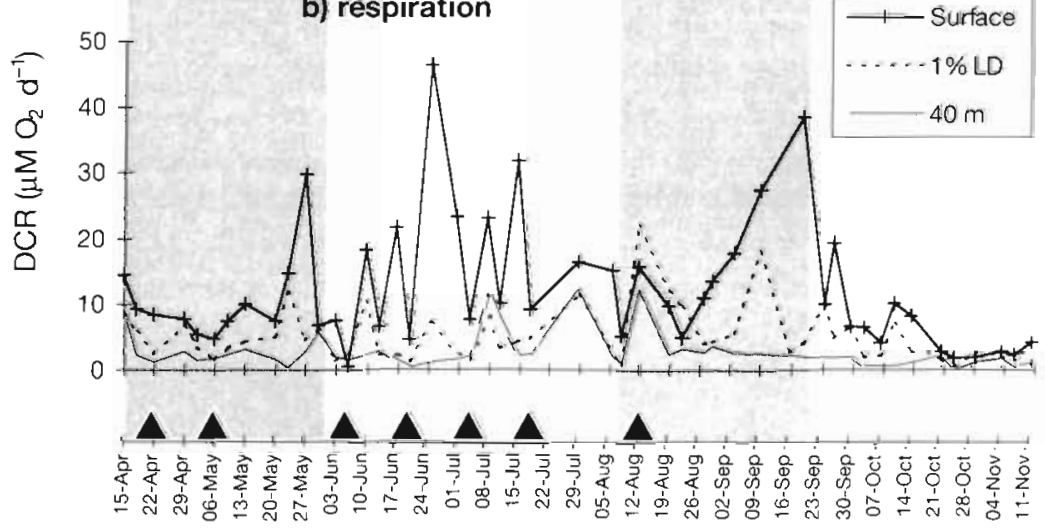

Fig. 5. Time-course from 15 April to 11 November 1991 of (a) gross oxygen production (GPP) at the surface and 1\% LD and (b) dark community respiration rates (DCR) at the surface, $1 \% \mathrm{LD}$ and $40 \mathrm{~m}$
The addition of a wide range of en vironmental variables such as incident irradiance, temperature, stratification or nutrient concentrations did not significantly increase the proportion of explained variance of GPP already accounted for by chl a concentrations. It was noted that while each upwellingrelaxation event was associated with an increase in GPP there was no consistent pattern relating the magnitude and timing of these increases relative to the hydrography and nitrate input into the euphotic layer.

At the $1 \%$ LD, GPP was on average an order of magnitude lower than at the surface (Table 1). The relationship between GPP and chl a was significant but weak (Table 2). Although populations at the $1 \%$ LD were certainly light limited, irradiance had no detectable effect on the relationship between GPP and chl a. On the other hand, the proportion of explained variance was significantly higher when both temperature and chl a were considered in the regression equation.

Assuming a range of PQs of 1.1 to 1.4 , the average GPP for the period of survey corresponded to an equivalent gross photosynthetic carbon production of 320 to $407 \mathrm{mg} \mathrm{C} \mathrm{m}^{-3} \mathrm{~d}^{-1}$ at the surface and 30 to $38 \mathrm{mg} \mathrm{C} \mathrm{m} \mathrm{m}^{-3} \mathrm{~d}^{-1}$ at the $1 \%$ LD. The mean between these 2 values integrated over the average depth of the euphotic zone during the period of survey $(12 \pm 4 \mathrm{~m})$ gave an estimated seasonal rate of integrated GPP of 2.1 to $2.7 \mathrm{~g} \mathrm{C} \mathrm{m}^{-2} \mathrm{~d}^{-1}$ (245 mmol $\mathrm{O}_{2} \mathrm{~m}^{-2} \mathrm{~d}^{-1}$ ). This corresponded to a total GPP of 441 to $561 \mathrm{~g} \mathrm{C} \mathrm{m}^{-2}$ for the period of sampling.

\section{Respiration rates}

The time-course of dark community respiration (DCR) rates exhibited considerable short-term variability, particularly pronounced during Period II (Fig. 5b). In contrast DCR tended to be low and uniform during spring (Period I) and autumn (Period IV). With very few exceptions, DCR decreased with depth giving an average respiration of 2 - and 
Table 1. Mean and standard deviation of gross primary production (GPP), chlorophyll-specific GPP (GPPch), dark community respiration (DCR) and net oxygen production (NP) at the surface, $1 \%$ light depth (LD) and $40 \mathrm{~m}$ calculated for the 4 periods defined in the text and for the entire period of survey from April to November 1991

\begin{tabular}{|lcccccc|}
\hline & & $\begin{array}{c}\text { Period I } \\
(\mathrm{n}=12)\end{array}$ & $\begin{array}{c}\text { Period II } \\
(\mathrm{n}=15)\end{array}$ & $\begin{array}{c}\text { Period III } \\
(\mathrm{n}=10)\end{array}$ & $\begin{array}{c}\text { Period IV } \\
(\mathrm{n}=13)\end{array}$ & $\begin{array}{c}\text { Sampling season } \\
(\mathrm{n}=50)\end{array}$ \\
\hline $\mathrm{GPP}$ & Surface & $38.6 \pm 22.8$ & $28.6 \pm 19.9$ & $38.6 \pm 23.7$ & $45.4 \pm 47.7$ & $37.3 \pm 30.7$ \\
$\left(\mu \mathrm{M} \mathrm{O} \mathrm{d}^{-1}\right)$ & $1 \% \mathrm{LD}$ & $3.2 \pm 3.1$ & $2.1 \pm 1.9$ & $5.2 \pm 7.0$ & $4.2 \pm 6.0$ & $3.6 \pm 4.8$ \\
$\mathrm{GPP}^{\mathrm{chl}}$ & Surface & $9.1 \pm 1.8$ & $7.5 \pm 4.3$ & $7.8 \pm 3.3$ & $7.3 \pm 4.0$ & $7.9 \pm 3.6$ \\
$\left.\left(\mu \mathrm{M} \mathrm{O}_{2} \mathrm{Hg}^{-1} \mathrm{chl} \mathrm{d}\right)^{-1}\right)$ & $1 \% \mathrm{LD}$ & $0.6 \pm 0.4$ & $1.3 \pm 1.4$ & $1.7 \pm 1.4$ & $1.1 \pm 1.2$ & $1.2 \pm 1.2$ \\
$\mathrm{DCR}$ & Surface & $10.5 \pm 6.8$ & $16.3 \pm 12.0$ & $16.0 \pm 10.9$ & $6.4 \pm 4.9$ & $12.2 \pm 9.8$ \\
$\left(\mu \mathrm{M} \mathrm{O}_{2} \mathrm{~d}^{-1}\right)$ & $1 \% \mathrm{LD}$ & $5.4 \pm 2.9$ & $4.5 \pm 3.5$ & $8.4 \pm 7.1$ & $3.7 \pm 2.9$ & $5.3 \pm 4.4$ \\
& $40 \mathrm{~m}$ & $3.0 \pm 2.5$ & $3.6 \pm 3.8$ & $4.0 \pm 3.8$ & $1.2 \pm 0.7$ & $2.8 \pm 3.0$ \\
$\mathrm{NP}$ & Surface & $28.1 \pm 23.8$ & $12.3 \pm 21.8$ & $22.6 \pm 22.9$ & $39.1 \pm 44.0$ & $25.2 \pm 30.8$ \\
$\left(\mu \mathrm{M} \mathrm{O}_{2} \mathrm{~d}^{-1}\right)$ & $1 \% \mathrm{LD}$ & $-2.2 \pm 2.2$ & $-2.5 \pm 2.4$ & $-3.4 \pm 6.1$ & $0.5 \pm 4.6$ & $-1.8 \pm 4.1$ \\
& $40 \mathrm{~m}$ & $-2.5 \pm 2.3$ & $-3.2 \pm 4.1$ & $-4.0 \pm 3.8$ & $-1.0 \pm 1.1$ & $-2.5 \pm 3.1$ \\
\hline
\end{tabular}

Table 2. Results of regression analyses relating gross primary production (GPP, $\mu \mathrm{M} \mathrm{O} \mathrm{O}^{-1}$ ) to chlorophyll concentration (chl, $\mu \mathrm{g}^{-1}$ ) for data from the surface and from the $1 \%$ light depth (LD). Regression equations were calculated using ordinary least squares (ols) and reduced major axis (rma) models. Stepwise multiple regression (smr) model was used to test the effect of selected environmental factors (nutrients, temperature $[T]$, irradiance, stratification) on the relationship between GPP and chl (only significant results are reported)

\begin{tabular}{|c|c|c|c|c|c|c|}
\hline Depth & Model & Regression equation & $R^{2}$ & $\mathrm{n}$ & $\mathrm{p}$ & Outlier \\
\hline Surface & $\begin{array}{l}\text { ols } \\
\text { rma }\end{array}$ & $\begin{array}{l}\mathrm{GPP}=7.36( \pm 0.63) \mathrm{chl}+3.95( \pm 3.78) \\
\mathrm{GPP}=8.50 \mathrm{chl}-2.32\end{array}$ & 0.75 & 47 & $<0.001$ & 9 Sep \\
\hline $1 \% \mathrm{LD}$ & $\begin{array}{l}\text { ols } \\
\text { rma } \\
\text { smr }\end{array}$ & $\begin{array}{l}\mathrm{GPP}=0.83( \pm 0.17) \mathrm{chl}+0.67( \pm 0.81) \\
\mathrm{GPP}=0.99 \mathrm{chl}-1.29 \\
\mathrm{GPP}=0.80( \pm 0.16) \mathrm{chl}+0.94( \pm 0.29) T-12.66( \pm 4.23)\end{array}$ & 0.34 & 48 & $<0.001$ & None \\
\hline
\end{tabular}

4 -fold greater at the surface than at the $1 \%$ LD and $40 \mathrm{~m}$ respectively (Table 1 ).

With the exception of the last upwelling event of the summer, periods of upwelling forcing were characterised by low DCR at all depths $\left(<10 \mu \mathrm{M} \mathrm{O}_{2} \mathrm{~d}^{-1}\right.$ at the surface, $<5 \mu \mathrm{M} \mathrm{O}_{2} \mathrm{~d}^{-1}$ at $1 \%$ LD and $<2 \mu \mathrm{M} \mathrm{O}_{2} \mathrm{~d}^{-1}$ at $40 \mathrm{~m}$ ). In contrast, the upwelling event on 12 August was associated with a sharp increase in respiration at the 3 depths sampled. Since, due to foggy weather conditions, the incubation time of this experiment had to be extended to $48 \mathrm{~h}$, the results obtained should be considered with caution. Nevertheless it is also possible that exceptionally high respiration rates measured in the upwelled water $\left(12.4 \mu \mathrm{M} \mathrm{O}_{2} \mathrm{~d}^{-1}\right.$ at $\left.40 \mathrm{~m}\right)$ were the result of enhanced in situ remineralisation associated with sediment resuspension by strong upwelling (Alvarez-Salgado et al. 1996b).

DCR was generally high during periods of nonupwelling forcing although in this case considerable variability was observed. High respiration activity was mainly observed in the surface layer. Maximum values were observed in June and September (up to 46.5 and $38.5 \mu \mathrm{M} \mathrm{O}_{2} \mathrm{~d}^{-1}$ on 25 June and 19 September respec- tively). The high value in September is particularly remarkable since it was reached at the end of a long period of low wind stress and high stratification during which DCR increased almost linearly with time and temperature in the surface layer. On 2 noticeable occasions in July high DCR rates were observed concomitantly at the surface, $1 \%$ LD and $40 \mathrm{~m}$, implying a major intensification of oxygen consumption in the ria. They took place during the relaxation phase of upwelling Events 5 and 6 when relatively warm, nitratepoor waters were present down to $40 \mathrm{~m}$. Interestingly, these waters were also rich in chl $a$ and were particularly well oxygenated (105 to $123 \%$ of oxygen saturation at the $1 \%$ LD, and 90 to $100 \%$ of oxygen saturation at $40 \mathrm{~m})$.

\section{Relationships between respiration, primary production and environmental variables}

DCR exhibited significant relationships with temperature and chl a (Table 3 ). When data from the 3 depths sampled were analysed together, both temperature 
Table 3. Coefficients of simple and multiple correlation and regression equations (ordinary least square) relating dark community respiration (DCR, $\mu \mathrm{M} \mathrm{O}_{2} \mathrm{~d}^{-1}$ ) to temperature $\left(T,{ }^{\circ} \mathrm{C}\right.$ ) and chlorophyll a $\left(\mathrm{chl}, \mu \mathrm{g} \mathrm{l}^{-1}\right)$ computed for data from the surface, $1 \% \mathrm{LD}, 40 \mathrm{~m}$ and for the whole data set ('Water column'). Also shown is the range of temperature and chlorophyll concentration covered by the analyses. $\cdots p \leq 0.001, \cdots 0.001<p \leq 0.01, \cdot 0.01<p \leq 0.05$, ns: not significant $(p>0.05$ ). Sample from 12 August was withdrawn from the correlation analysis at the $1 \% \mathrm{LD}$ and at $40 \mathrm{~m}$

\begin{tabular}{|c|c|c|c|c|c|c|}
\hline \multirow[t]{2}{*}{ Depth } & \multirow[t]{2}{*}{$\mathrm{n}$} & \multicolumn{3}{|c|}{ Coefficients of correlation (R) with DCR } & \multicolumn{2}{|c|}{ Range of variation } \\
\hline & & $T$ & Chl & $T+\mathrm{Chl}$ & $T\left({ }^{\circ} \mathrm{C}\right)$ & Chl $\left(\mu g ~^{-1}\right)$ \\
\hline Surface & 48 & $0.50^{\cdots}$ & $0.29^{\circ}$ & $0.50 \cdots$ & $12.64-21.03$ & $0.16-17.47$ \\
\hline $1 \% \mathrm{LD}$ & 48 & $0.38 \cdots$ & $0.66^{\cdots}$ & $0.74 \cdots$ & $12.04-18.51$ & $0.21-14.63$ \\
\hline $40 \mathrm{~m}$ & 45 & ns & $0.59 \cdots$ & $0.59 \cdots$ & $11.66-15.03$ & $0.05-6.63$ \\
\hline Water column & 140 & $0.58 \cdots$ & $0.48 \cdots$ & $0.66 \cdots$ & $11.66-21.03$ & $0.05-17.47$ \\
\hline \multicolumn{7}{|c|}{ Regression equations } \\
\hline Surface & \multicolumn{6}{|c|}{$\mathrm{DCR}=2.25( \pm 0.57) T-23.54( \pm 9.16)$} \\
\hline $1 \%$ LD & \multicolumn{6}{|c|}{$\mathrm{DCR}=0.71( \pm 0.21) T+0.73( \pm 0.11) \mathrm{chl}-7.64( \pm 2.97)$} \\
\hline $40 \mathrm{~m}$ & \multicolumn{6}{|c|}{$\mathrm{DCR}=0.81( \pm 0.17) T+1.00( \pm 0.48)$} \\
\hline Water column & \multicolumn{6}{|c|}{$D C R=1.75( \pm 0.24) T+0.77( \pm 0.16) \mathrm{chl}-21.21( \pm 3.41)$} \\
\hline
\end{tabular}
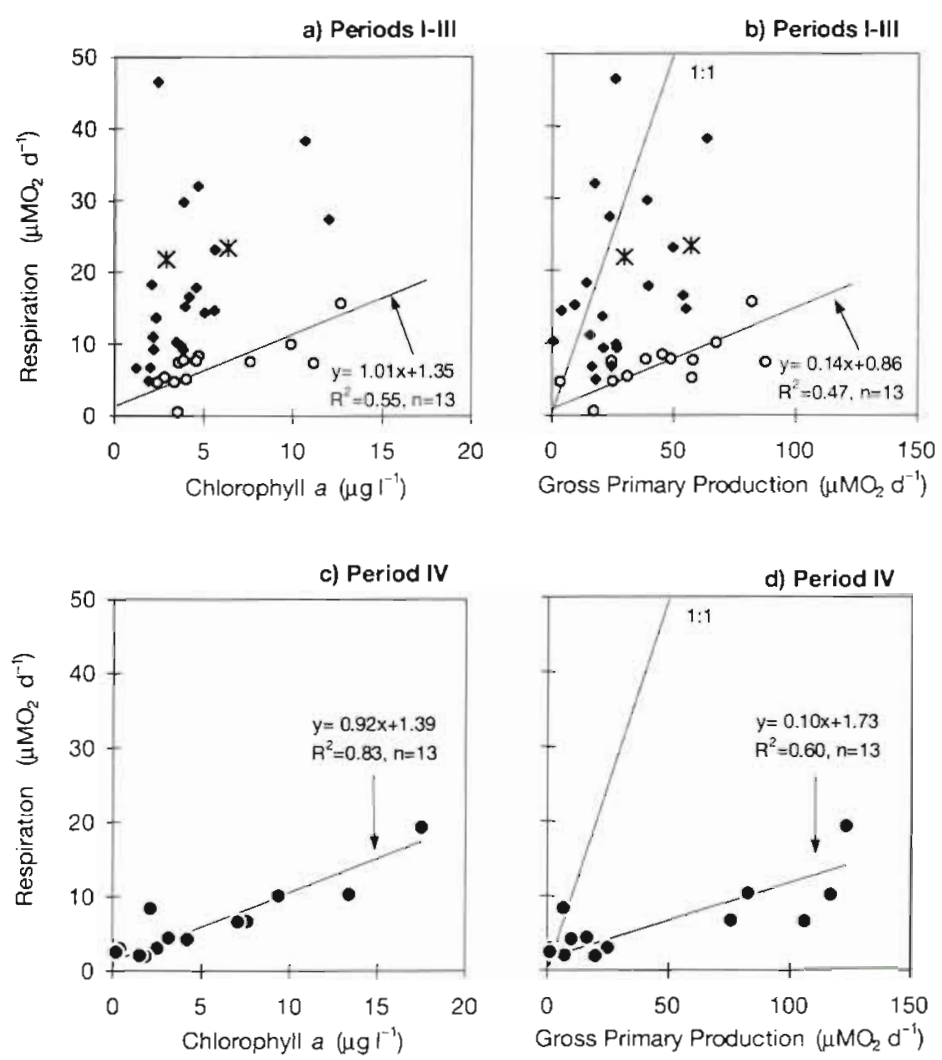

Fig. 6. Surface DCR versus chlorophyl concentration and surface DCR versus GPP for $(a, c)$ Periods I to III and $(b, d)$ Period IV. Datapoints (o) corresponding to strong and moderate upwelling were used for the calculation of the regression lines on (a) and (b) ( $*$ : outliers from the linear regression). ( $\bullet$ ) Datapoints associated with upwelling relaxation or weak upwelling events on (a) and (b). All regression lines were calculated according to the reduced major axis model (equations derived from the ordinary least square model were as follows: [a] $\mathrm{DCR}=0.75[ \pm 0.21] \mathrm{chl} a+2.85[ \pm 1.35]$, [b] $\mathrm{DCR}=$ $0.10[ \pm 0.03] \mathrm{GPP}+2.83[ \pm 1.56],[\mathrm{c}] \mathrm{DCR}=0.84[ \pm 0.11] \mathrm{chl} a+$ $1.83[ \pm 0.85],[\mathrm{d}] \mathrm{DCR}=0.08[ \pm 0.02] \mathrm{GPP}+2.77[ \pm 1.25]$ and chl $a$ accounted for a significant proportion of the total variance of $D C R$. However the strength of the correlation between temperature and DCR decreased with depth, being highly significant at the surface, significant but weak at the $1 \%$ LD and not significant at $40 \mathrm{~m}$. In contrast, the correlation between chl a and DCR was stronger at the $1 \% \mathrm{LD}$ and $40 \mathrm{~m}$ than at the surface, where only $8 \%$ of the total variance of $D C R$ was accounted for by chl a. Stepwise multiple regression analysis was used to investigate potential interactions between chl $a$ or GPP and temperature in the control of respiration rates. It resulted in no further increase of the explained variance at the surface and at $40 \mathrm{~m}$ (Table 3). On the other hand, at the 1\% LD and when data from the 3 depths were compiled together, both chl $a$ and temperature contributed independently for a significant proportion of the variance of DCR. On all instances the best fit model was linear (Table 3).

The scatter plots of DCR versus chl a and versus GPP (Fig. 6) provide some interesting information about the short-term coupling between phytoplankton production and community respiration in the surface layer. For clarity, data corresponding to Period IV are presented on separate plots (Fig. 6c,d) from data collected during Periods I to III (Fig. 6a,b). During Periods I to III considerable scatter was observed in the relationship between DCR and chl a (Fig. 6a) and between DCR and GPP (Fig. 6b). However we noted that data points associated with periods of moderate to strong upwelling (that is events strong enough to induce a significant decrease in surface temperature) and distinguished by open symbols on Fig. 6 exhibited strong linear relationships between the variables. With the exclusion of 2 outliers (17 June and 1 July) which corresponded to the early stage of Events 4 and 5, the regression equations (reduced major axis model) of DCR versus chl $a$ and 
of DCR against GPP within this group ( $\mathrm{n}=13$ ) indicated a low residual oxygen consumption $(0.9$ to $1.3 \mu \mathrm{M} \mathrm{O}_{2} \mathrm{~d}^{-1}$ ) and a phytoplankton-dependent respiration rate of $1.0 \pm 0.3 \mu \mathrm{mol} \mathrm{O} \mathrm{O}_{2} \mathrm{gg}^{-1} \mathrm{chl} \mathrm{d} \mathrm{d}^{-1}$ or $0.14 \pm$ 0.04 of GPP. Remarkably similar functional relationships between DCR and chl $a$ and between DCR and GPP were also observed for the whole of Period IV (Fig. 6c,d).

\section{Microplankton net community production}

Net daily oxygen production (NP) averaged over the sampling season indicated net autotrophy of $+25 \mu \mathrm{M}$ $\mathrm{O}_{2} \mathrm{~d}^{-1}$ at the surface and slight net heterotrophy at the level of $1 \%$ LD (Table 1). At $40 \mathrm{~m}$, NP did not differ

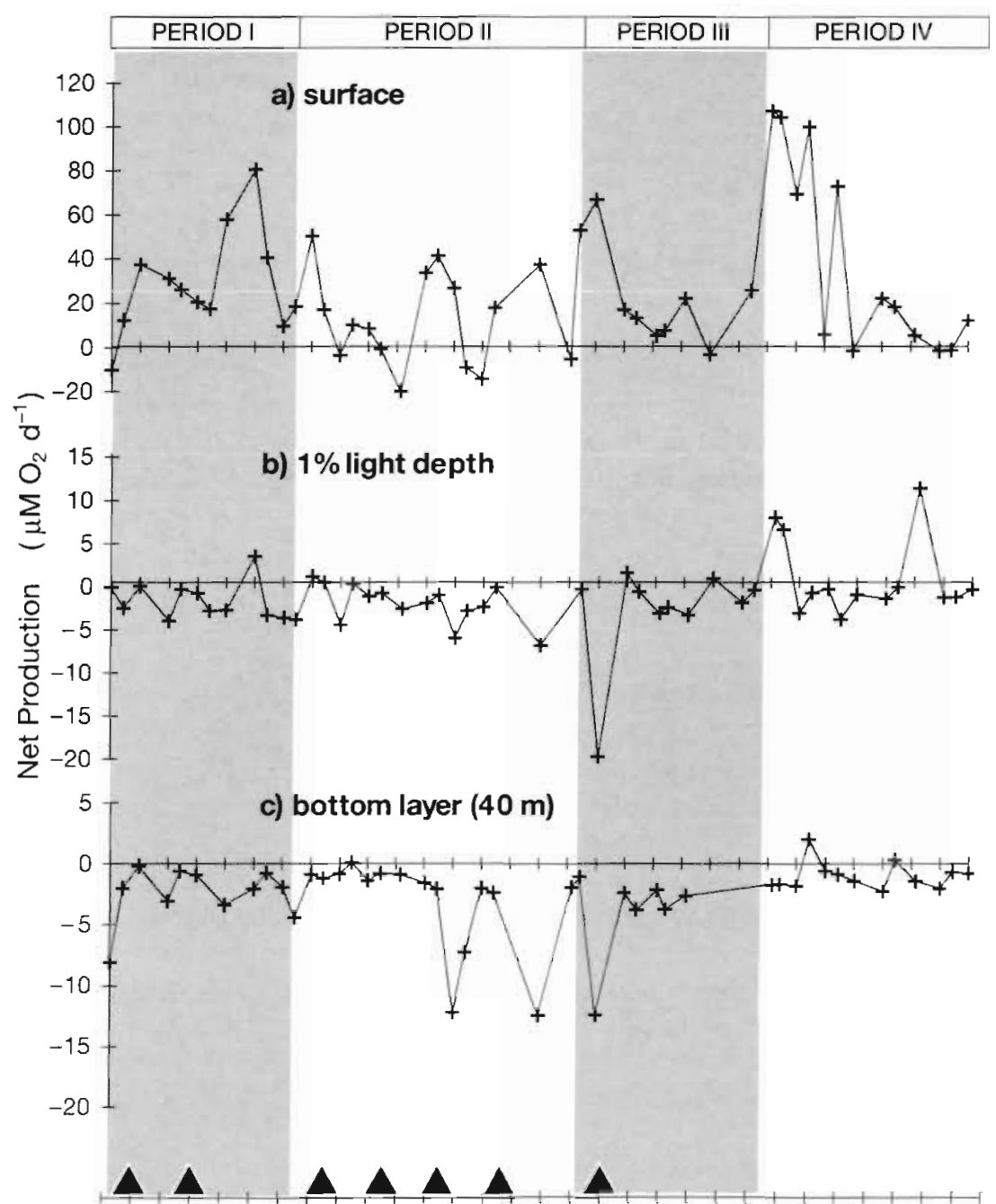

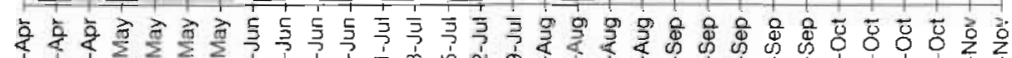

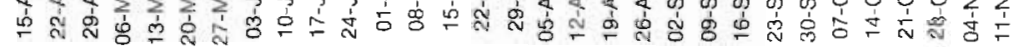

Fig. 7. Time-course from 15 April to 11 November 1991 of net microplankton community production at (a) the surface, (b) $1 \%$ LD and (c) $40 \mathrm{~m}$ significantly from DCR. At the surface only 11 of the 50 observations showed a negative oxygen balance after $24 \mathrm{~h}$ incubation (Fig. 7). Significant net heterotrophy at the surface was mainly observed during periods of high stratification in June and July, reaching values of $-21 \mu \mathrm{M} \mathrm{O}_{2} \mathrm{~d}^{-1}$ on 25 July and -10 to $-15 \mu \mathrm{M} \mathrm{O}_{2} \mathrm{~d}^{-1}$ on 11 to 15 July. At the $1 \%$ LD, only 8 out of 50 observations showed net oxygen production after $24 \mathrm{~h}$, with higher values being grouped in autumn (Period IV). This indicates that, during the major part of the upwelling season, the microplankton community compensation point was located above the $1 \%$ LD.

The overall seasonal distribution of NP presented 2 clear maxima during Periods I and IV (Fig. 7, Table 1). The mean between seasonal average NP at the surface and at the $1 \%$ LD integrated over the depth of the euphotic zone gave an estimated integrated seasonal rate of NP in the euphotic zone of $140 \mathrm{mmol} \mathrm{O}_{2} \mathrm{~m}^{-2} \mathrm{~d}^{-1}$ (equivalent to $1.2-1.5 \mathrm{~g} \mathrm{C} \mathrm{m}^{-2} \mathrm{~d}^{-1}$ ). The mean between seasonal average NP at the $1 \% \mathrm{LD}$ and $40 \mathrm{~m}$ integrated over the average depth of the aphotic layer $(28 \mathrm{~m})$ gave an estimated NP in the aphotic zone of $-60 \mathrm{mmol} \mathrm{O}_{2} \mathrm{~m}^{-2} \mathrm{~d}^{-1}$.

\section{DISCUSSION}

\section{Phytoplankton production during the upwelling season 1991}

The overall seasonal evolution of the hydrographic parameters and phytoplankton biomass during the 1991 field study followed the typical pattern previously described for the Ria de Vigo during the upwelling season (Margalef 1958, Nogueira et al. 1997). Maxima of biomass (chl a $>15 \mu \mathrm{g} \mathrm{l}^{-1}$ ) and photosynthetic production (GPP $>80 \mu \mathrm{M}$ $\mathrm{O}_{2} \mathrm{~d}^{-1}$ ) occurred during the early spring and the early autumn, preceding the spring thermal stratification and the autumn thermal homogenisation as typically observed in most temperate coastal ecosystems. During the summer, episodic increases in phytoplankton production and biomass of variable intensity were closely related to the upwelling of nutrient-rich water into the euphotic zone.

The level of primary production encountered during the upwelling season 1991 is considerably higher than previ- 
ously reported for the Ria de Vigo. Both discrete rates in the surface layer and seasonal estimates of GPP were at least twice as high as that observed at an inner station in the Ria de Vigo and based on carbon-14 uptake (Fraga 1976). A number of methodological uncertainties have long been associated with both carbon-14 and the oxygen light-dark bottle techniques (Peterson 1980, Williams 1984). For the oxygen technique the main uncertainty relates to the effect of artificially prolonged dark treatment on the metabolic activity and trophic relationships of natural microplankton communities. A recent study of oxygen consumption in the dark (Pomeroy et al. 1994) showed that although oxygen decrease was often non linear over $24 \mathrm{~h}$ the absolute difference between 12 and $24 \mathrm{~h}$ incubation periods was small (averaging $\pm 28 \%$ or $1.4 \mu \mathrm{M}$ $\mathrm{O}_{2} \mathrm{~d}^{-1}$ ) and exhibited no systematic trend. It is therefore unlikely that such bias would have introduced a large systematic error on our GPP rates. Also while it is now well established that early ${ }^{14} \mathrm{C}$-uptake methodology tended to underestimate primary production (Peterson 1980) it is unlikely that methodological bias alone was responsible for the differences observed between the 2 studies considering that the station sampled in Fraga's study was located in an area of the ria where production is usually maximal (Prego 1993). The high sampling frequency used in the present study ( 3 to 4 d) compared with the reference study (monthly sampling) would have minimised the error associated with temporal undersampling, which can reach $\pm 35 \%$ for monthly sampling intervals in variable ecosystems (Taylor \& Howes 1994). Interannual variability in the wind regime can also be an important source of yearto-year variability of phytoplankton production in upwelling areas (Barber \& Smith 1981). Intensive seasonal measurements of primary production within the Iberian upwelling system are yet too scarce to quantify this effect on phytoplankton production. However, such a relationship was implied by the results of Blanton et al. (1987), showing that a 2-fold year-to-year variation of the meat quality of harvested mussels in the rias could be accounted for by interannual variations in upwelling intensity along the Galician coast. Although several recent studies have pointed to the occurrence of a long-term increase in upwellingfavourable winds in this area (Fraga \& Bakun 1993, Binet 1997, Nogueira et al. 1997), the wind regime in 1991 could be considered typical for the NW Iberian upwelling system with a mean Iw from April to September $\left(+394 \mathrm{~m}^{3} \mathrm{~s}^{-1} \mathrm{~km}^{-1}\right)$ very near the $16 \mathrm{yr}$ average presented by Blanton et al. (1987) for the same period of the year from 1969 to $1985\left(+379 \pm 182 \mathrm{~m}^{3} \mathrm{~s}^{-1} \mathrm{~km}^{-1}\right)$. The oscillations in alongshore wind stress also presented the typical period of 10 to $20 \mathrm{~d}$ (Blanton et al. 1987 ). Since runoff and insolation tend to covary with poleward wind trends in this area, seasonal primary production rates measured in 1991 should therefore be representative of a typical upwelling season.

A seasonal mean rate of integrated gross production of 2.1 to $2.7 \mathrm{~g} \mathrm{C} \mathrm{m}^{-2} \mathrm{~d}^{-1}$ was estimated in the present study. Although this estimate should be considered carefully because of the lack of sampling resolution in the euphotic zone, it constitutes to date the best estimate of seasonal integrated GPP for the Ria de Vigo. The accuracy of this estimated seasonal integrated GPP was tested by using the results from a recent study of photosynthesis in the Ria de Vigo (Figueiras unpubl.). Integrated GPP rates calculated by linear interpolation between surface and 1\% LD discrete values were compared with integrated rates calculated from the light attenuation profile and photosynthetic parameters derived from photosynthesis versus irradiance curves. The data set covered spring, summer and autumn periods and included distinct upwelling and relaxation phases. It was found that linear interpolation overestimated water column primary production by on average $18 \%$ but by no more than $22 \%$. We can therefore be confident that the possible overestimation of seasonal integrated GPP in the present study would not have exceeded this figure. The seasonal rates reported here are in very good agreement with the seasonal average of $2.1 \mathrm{~g} \mathrm{C} \mathrm{m}^{-2} \mathrm{~d}^{-1}$ derived from intensive ${ }^{14} \mathrm{C}$-uptake measurements series in the middle segment of the nearby Ria de Arosa during the upwelling season (1989) (Alvarez-Salgado et al. 1996a). Comparison with other upwelling systems for which primary production was measured over either complete upwellingrelaxation cycles or entire upwelling season indicated that the rate of primary production in the Ria de Vigo is comparable to averaged values recently reported for the NE Pacific (2.6 $\mathrm{g} \mathrm{C} \mathrm{m}^{-2} \mathrm{~d}^{-1}$; Pilskaln et al. 1996), NW African (0.7 to $4.7 \mathrm{~g} \mathrm{C} \mathrm{m}^{-2} \mathrm{~d}^{-1}$; Minas et al. 1986) and Benguela (3.5 $\mathrm{g} \mathrm{C} \mathrm{m}^{-2} \mathrm{~d}^{-1}$; e.g. Brown \& Field 1986 , Pitcher et al. 1996) upwelling systems.

\section{Heterotrophic activity and its coupling to primary production during the upwelling season}

The present study demonstrated that the Ria de Vigo was the site of considerable pelagic heterotrophic activity. The rates of dark community respiration (DCR) measured in the euphotic zone were high relative to reported values for the upper water column of coastal and open-shelf upwelling areas (range: 0.1 to $20 \mu \mathrm{M}$ $\mathrm{O}_{2} \mathrm{~d}^{-1}$, Williams 1984). The seasonal mean of $12 \mu \mathrm{M}$ $\mathrm{O}_{2} \mathrm{~d}^{-1}$ and maximum rates above $30 \mu \mathrm{M} \mathrm{O}_{2} \mathrm{~d}^{-1}$ in the surface layer lie in the upper range of values reported for seasonal studies in various unpolluted coastal and lower estuarine areas (Hopkinson 1985, Kuparinen 
1987, Jensen et al. 1990, Kemp et al. 1992, Blight et al. 1995). Though short-term variability of respiration rates as high as that observed in the present study has not been previously reported, the vertical and longterm seasonal distribution of DCR in the Ria de Vigo presented an overall pattern similar to that observed in another seasonally stratified coastal system in the Baltic Sea (Kuparinen 1987). On average oxygen consumption was higher during the thermally stratified season (June to September) than during spring and autumn and this pattern was mainly observed in the surface layer.

Both physical and biological factors were important in explaining the seasonal and vertical distribution of DCR in the Ria de Vigo. Over the period of sampling, half of the total variance of DCR could be accounted for jointly by temperature and chlorophyll concentration. However the relative importance of these 2 variables was different for the 3 depths studied. In the surface layer temperature was the most important factor explaining $25 \%$ of the temporal variations of $\mathrm{DCR}$, while in the bottom layer only chlorophyll accounted for a significant proportion $(35 \%)$ of the variations of respiration. At the $1 \%$ LD both variables were equally important and accounted jointly for $55 \%$ of the variations observed. Remarkably a similar vertical segregation in the relative importance of biological and physical factors was obtained for bacterial abundance in a contemporaneous study carried out in the Ria de Vigo (Zdanowsky \& Figueiras 1997). Since in both studies temperature and chlorophyll concentration had a positive effect on either respiration or bacterial abundance, the parallel between the two points to a significant contribution of bacterial respiration to the seasonal distribution of DCR in both the euphotic and aphotic layers. This is in good agreement with previous studies that have shown the importance of free-living bacteria in the distribution of pelagic respiration in various coastal areas (Kuparinen 1987, Griffith et al. 1990, Blight et al. 1995). The significant correlation between respiration and chlorophyll concentration in the aphotic layer implies that heterotrophic activity in the bottom layer was primarily controlled by the supply of organic substrate from sedimenting phytoplankton biomass. However we noted that the relationship between respiration and chl a was more scattered at the highest chlorophyll concentrations ( 3.0 to $6.6 \mu \mathrm{g} \mathrm{l}^{-1}$ ), suggesting that other factors probably related to the quality and lability of the sedimented material were also important in controlling the rate of oxygen consumption in the aphotic layer.

The significant correlation between DCR and temperature in the surface layer reflected the importance of physical factors in the control of heterotrophic activity in the euphotic zone in the Ria de Vigo. The absence of a stronger relationship between DCR and phytoplankton biomass or production in the surface layer may at first seem surprising in a system dominated by phytoplankton production (Blight et al. 1995). Stronger correlation with temperature rather than phytoplankton biomass or production have often been observed in coastal systems where allochthonous sources of organic matter dominates over in situ production (Hopkinson 1985). However this is not the case in the Ria de Vigo, where inputs of terrestrial and anthropogenic organic matter to the middle segment of the Ria de Vigo are negligible compared with in situ phytoplankton production ( $<2 \%$; Prego 1993). On the other hand a significant correlation between surface respiration rates and temperature in upwelling systems could reflect the dominant role of upwelling processes in controlling the degree of coupling between phytoplankton production and heterotrophic consumption. Close observation of the scatter plots between DCR and chl $a$ or GPP in the surface layer clearly showed 2 contrasting situations between periods of upwelling forcing and periods of upwelling relaxation. Both situations were characterised by a similar range of chl a concentrations but exhibited marked differences in the balance between primary production and community respiration. In situations of strong or moderate upwelling the microplankton community exhibited low but phytoplankton-dependent respiration rates. With the exception of 2 outliers the linear relationships between DCR and chl a concentrations and between DCR and GPP $\left(R^{2}=0.5, n=13\right)$ defined a minimum 'basic' community respiration rate which could be statistically decomposed into a residual respiration rate of ca $1 \mu \mathrm{M} \mathrm{O}_{2} \mathrm{~d}^{-1}$ and a phytoplankton-dependent oxygen consumption of $1.0 \pm 0.3 \mu \mathrm{mol} \mathrm{O}_{2}{\mu \mathrm{gg}^{-1} \mathrm{chl} \mathrm{a} \mathrm{d}}^{-1}$ or $14 \pm 4 \%$ of GPP respectively. In contrast, in situations of upwelling relaxation or weak upwelling DCR was high relative to chl a concentration and the scatter between DCR and GPP was closer to the line of balance metabolism where DCR = GPP. This pattern is consistent with observations of phytoplankton succession in the na, which showed that complex mixed communities of autotrophic and heterotrophic species dominate in the surface layer under conditions of reduced coastal upwelling while essentially autotrophic diatom-dominated communities become dominant during upwelling events (Figueiras \& Pazos 1991, Figueiras \& Ríos 1993). The 2 exceptions to the low respiration rates in upwelled waters corresponded to the early stage of 2 of the summer upwelling events and could therefore have reflected a transition stage between these communities. The large scatter characterising the relationship between DCR and chl $a$ or GPP under conditions of reduced coastal upwelling indicated that the degree of heterotrophy of the micro- 
plankton communities can vary widely. This variability agrees well with the description of horizontal trophic sequence in upwelling areas (Vinogradov \& Shushkina 1978). The fact that these variations were sometimes observed on a short daily time-scale at the time-series station was very likely due to the advective transport of surface waters. Part of this variability should therefore be not only representative of the temporal evolution of microplankton communities following upwelling but also of spatial heterogeneity in the ria.

Significant net heterotrophy during the summer suggested that substantial heterotrophic production must have been supported by organic substrates derived from earlier phytoplankton production trapped inside the bay once upwelling had stopped. Recent seasonal studies have underlined the importance of biologically produced dissolved organic material in the Galician Rias and linked it to the large presence of hanging mussel culture in these bays. Alvarez-Salgado et al. (1996a) showed that on average $58 \%$ of the pelagic net community nitrogen production was transferred to the dissolved organic pool in the Ria de Arosa. In the Ria de Vigo the production of labile and semi-labile dissolved organic carbon represented about $23 \%$ of net primary production (Doval et al. 1997). Hanging mussels can contribute to the trapping of phytoplankton production produced during upwelling events and to its release in the water column as dissolved organic matter (AlvarezSalgado et al. 1996a). Excretion products would be expected to accumulate in situations of reduced estuarine circulation in the ria and could form the start of a food chain of a more heterotrophic character. This is an important consideration since the flux of regenerated nutrients to the euphotic zone under conditions of high stratification is thought to play an important role in the development of red tides in the Galician Rias (Tilstone et al. 1994, Pazos et al. 1995). Remineralisation in the euphotic zone of a pool of organic matter originating from earlier diatom production could provide an important source of nutrient for phytoplankton production during periods of upwelling relaxation.

The phytoplankton-dependent respiration rate derived from the linear relationship between DCR and chl a concentrations during upwelling events in the ria is within the range of maximum chlorophyll-specific dark respiration rates for cultures of diatom species (DR ${ }^{\text {chl }} 0.6$ to $1.3 \mu \mathrm{mol} \mathrm{O}{ }_{2}{\mu g^{-1}} \mathrm{chl} \mathrm{a} \mathrm{d}{ }^{-1}$ ) calculated from the data compiled by Langdon (1993). Similar values were also observed in the North Sea for microplankton communities dominated by diatoms (Iriarte et al. 1991). The slope of the relationship between DCR and GPP indicated that $14 \pm 4 \%$ of GPP was lost through community respiration. This value agrees also well with results from the NW African upwelling system, where natural phytoplankton assemblage dominated by dia- toms respired on average $13 \%$ of the previously fixed photosynthetic carbon (Smith 1977). It is also within the range of the DCR:GPP ratio of 10 to $20 \%$ observed during the spring diatom bloom in the Baltic Sea (Kuparinen 1987). It is therefore likely that variations of DCR in the upwelled waters were mainly due to phytoplankton respiration. Interestingly similar conclusions can be reached for the extended period of the autumn bloom at the end of the upwelling season. The bloom was dominated by diatoms and took place during a period of enhanced estuarine circulation generated by a combination of moderate northerly winds and high runoff which led to the seasonal breakdown of thermal stratification. DCR was remarkably low in the surface layer and presented a linear relationship with phytoplankton biomass and production which was not significantly different from that observed in upwelled waters during spring and summer. These results imply that the proportion of GPP respired by microheterotrophs during upwelling events and during the autumn bloom was probably low. Although this is in contrast with situations observed across a wide range of aquatic systems (Cole et al. 1988, del Giorgio et al. 1997), it concords with reports of low bacterial respiration and production relative to phytoplankton production during diatom spring blooms in temperate and subpolar area (Kuparinen 1987, Cole et al. 1988, Pomeroy et al. 1991, Blight et al. 1995). The reasons for low bacterial activity under such situations are not clearly understood. In the present study the initial effect of dilution by the upwelled water on bacterial biomass (Zdanowsky \& Figueiras 1997), the potential effect of low temperature on bacterial metabolism and growth (Pomeroy et al. 1991) and the enhanced flushing rate associated with the enhanced positive estuarine circulation preventing the accumulation of dissolved organic substrates (Alvarez-Salgado et al. 1996b) could all have contributed to delay the response of bacterial populations to an increase in phytoplankton production.

\section{Net community production during the upwelling season}

In systems dominated by autotrophic processes and with limited allochthonous inputs of organic matter, net community production (NP) integrated over an appropriate time-scale is a measurement of new production (Quiñones \& Platt 1991). The ratio of the mean seasonal rates of NP and GPP (NP:GPP) provides a useful estimate of the fraction of total primary production available for export from a given system (equivalent to the $f$-ratio defined by Eppley \& Peterson 1979). We estimated that, over the period of sur- 
vey, integrated net production in the euphotic zone was $140 \mathrm{mmol} \mathrm{O}_{2} \mathrm{~m}^{-2} \mathrm{~d}^{-1}$ (equivalent to $1.2-1.5 \mathrm{~g} \mathrm{C}$ $\mathrm{m}^{-2} \mathrm{~d}^{-1}$ ), giving an average NP:GPP ratio of 0.57 . This value is comparable to that obtained for the nearby Ria de Arosa (Alvarez-Salgado et al. 1996a) using a non-steady state box model and intensive ${ }^{14} \mathrm{C}$-uptake measurement series. In this case an $f$-ratio of 0.63 was calculated for an average plankton net community production of $1.3 \mathrm{~g} \mathrm{C} \mathrm{m}^{-2} \mathrm{~d}^{-1}$. Such high $f$-ratios are characteristic of highly productive marine ecosystems and uncoupled shelf food webs (Eppley 1989, Walsh 1991). In the aphotic layer, net oxygen production rates integrated between the $1 \%$ LD and $40 \mathrm{~m}$ projected a seasonal average net oxygen consumption of $-60 \mathrm{mmol} \mathrm{m}{ }^{-2} \mathrm{~d}^{-1}$, indicating that the equivalent of $43 \%$ of euphotic zone net production was remineralised below the $1 \%$ LD. This figure compares remarkably well with the value of $40 \%$ previously estimated for the Ria de Vigo using a steady-state box model (Prego 1993). It follows that $33 \%$ of euphotic zone GPP produced during the period of survey (an estimated 0.7 to $0.9 \mathrm{~g} \mathrm{C} \mathrm{m}^{-2} \mathrm{~d}^{-1}$ ) was not remineralised in the water column and was therefore available for transfer to higher trophic levels, sedimentation in the ria and export towards the shelf.

The present study showed that periods of strong or moderate upwelling and the autumn period contributed a high proportion of the total net production measured during the period of survey ( 41 and $40 \%$ respectively in the surface layer). The high rate of net production during the autumn period is particularly remarkable. Unlike the situation observed during the spring and summer when there was some evidence of in situ sedimentation of phytoplankton biomass and remineralisation in the aphotic layer following phytoplankton blooms, the autumn phytoplankton bloom was not followed by an increase in pelagic respiration and there was no evidence of sedimentation of phytoplankton biomass in the ria. High ammonium concentrations during this period could suggest that grazing pressure by macrozooplankton was high. However increases in ammonium concentration tended to coincide with periods of high runoff, suggesting that they originated from the transport of ammonium from the inner part of the ria where seasonal decomposition of large population of macrophytes occurs in autumn (Pérez et al. 1992) and large quantities of ammonium are released from the sediments (Alvarez-Salgado et al. 1996b). Therefore the large excess production of the autumn bloom in 1991 did not appear to have been remineralised in the ria and was probably exported towards the shelf. This observation implies that the autumn bloom may contribute a high proportion to the annual export of primary production in this area.

\section{SUMMARY AND CONCLUSIONS}

This work was to our knowledge the first seasonal study of the short-term coupling between primary production and community respiration in an ecosystem dominated by upwelling processes. The high shortterm variability observed for both primary production and dark community respiration rates stressed the importance of high frequency sampling programmes in this type of environment. Both physical and biological factors were important in controlling the rate of oxygen consumption in the water column. We found that half of the total seasonal and vertical variance of DCR rates could be explained on the basis of a simple relationship with temperature and chl a concentrations. The relationship with temperature in particular suggested that temperature might be a good proxy for more complex physical and biological processes associated with the succession of upwelling and relaxation cycles in the ria. This was particularly evident in the surface layer, where the degree of coupling between primary production and community respiration was strongly influenced by upwelling. The results of this study indicated that during upwelling events respiration losses represented a consistently low percentage of primary production. Although high respiration rates and high DCR:GPP ratios were generally observed during periods of relaxation, the seasonal balance between primary production and respiration indicated that a large fraction of phytoplankton production $(33 \%)$ was available for export from the water column. Persistent low respiration rates and apparent low sedimentation rates during the autumn period underlined the important contribution of the autumn bloom to the seasonal export of organic matter from the ria.

Acknowledgements. The authors thank the staff of Queen's University Marine Laboratory in Portaferry and of the Grupo de Oceanoloxia at the Instituto de Investigacions Marinas in Vigo for their help and support during the project and in particular Philip Johnston and Mick Curran at Queen's University (preparation of fieldwork equipment), and Ana Mosquera (chlorophyll analyses and phytoplankton identification and Ramon Penin (salinity analyses) in Vigo. Special thanks go to Ricardo Casal Casal, Captain of the RV 'Lampadena' of the IIM, Vigo, for his assistance during the work at sea. The project was funded by the EU MAST Contract CT90-0017 'Control of Phytoplankton Dominance'. G.M. is grateful to the British Council for a 6 mo fellowship which enabled her to continue her study at the Queen's University of Belfast. X.A.A.-S. acknowledges support from a visiting fellowship of the Departamento de Postgrado $y$ Especializacion (CSIC) during the preparation of the paper.

\section{LITERATURE CITED}

Alvarez-Salgado XA, Pérez FF, Fraga F (1992) Determination of nutrient salts by automatic methods both in seawater and brackish water. Mar Chem 39:311-319 
Alvarez-Salgado XA, Rosón G, Pérez FF, Pazos Y (1993) Hydrographic variability off the Rias Baixas (NW Spain) during the upwelling season. J Geophys Res 98(C8):14447-14455

Alvarez-Salgado XA, Rosón $G$, Pérez FF, Figueiras FG, Pazos $Y$ (1996a) Nitrogen cycling in an estuarine upwelling system, the Ria de Arousa (NW Spain). I. Short-time-scale patterns of hydrodynamic and biogeochemical circulation Mar Ecol Prog Ser 135:259-273

Alvarez-Salgado XA, Rosón G, Pérez FF, Figueiras FG, Pazos $Y$ (1996b) Nitrogen cycling in an estuarine upwelling system. the Ria de Arousa (NW Spain). II. Spatial differences in the short-time-scale evolution of fluxes and net budgets. Mar Ecol Prog Ser 135:259-273

Alvarez-Salgado XA, Castro CG, Pérez FF, Fraga F (1997) Nutrient mineralisation patterns in shelf waters off the western Iberian Upwelling. Cont Shelf Res 17:1247-1270

Bakun A (1973) Coastal upwelling indices, west coast of North America, 1946-71. NOAA Tech Rep NMFS 671, US Department of Commerce, Washington, DC

Barber RT. Smith RL (1981) Coastal upwelling ecosystems. In: Longhurst AR (ed) Analysis of marine systems. Academic Press, San Diego, p 31-68

Binet D (1997) Climate and pelagic fisheries in the Canary and Guinea currents 1964-1993: the role of trade winds and southern oscillation. Oceanol Acta 20:177-190

Blanton JO, Atkinson LP, Castillejo FF, Lavin A (1984) Coastal upwelling off the Rias Bajas, Galicia, Northwest Spain, I: Hydrographic studies. Rapp PV Reun Cons Int Explor Mer 183:79-90

Blanton JO, Tenore KR, Castillejo FF, Atkinson LP, Schwing FB, Lavin A (1987) The relationship of upwelling to mussel production in the rias on the western coast of Spain. J Mar Res 45:497-511

Blight SP, Bentley TL, Lefevre D, Robinson C, Rodrigues $R$, Rowlands J. Williams PJleB (1995) Phasing autotrophic and heterotrophic plankton metabolism in a temperate coastal ecosystem. Mar Ecol Prog Ser 128:61-75

Bowden KF (1980) Physical factors: salinity, temperature, circulation and mixing processes. In: Olausson E Cato I (eds) Chemistry and biogeochemistry of estuaries. Wiley \& Sons, Chichester, p 37-70

Brown PC, Field JG (1986) Factors limiting phytoplankton production in a nearshore upwelling area. J Plankton Res $8: 55-68$

Carrit DE, Carpenter JH (1966) Comparison and evaluation of currently employed modifications of the Winkler method for determining dissolved oxygen in seawater; a NASCO report. J Mar Res 24:286-317

Castro CG, Pérez FF, Alvarez-Salgado XA, Rosón G, Ríos AF (1994) Hydrographic conditions associated with the relaxation of an upwelling event off the Galician coast (NW Spain). J Geophys Res 99(C3):5135-5147

Cole JJ, Findlay S, Pace ML (1988) Bacterial production in fresh and saltwater ecosystems: a cross-system overview. Mar Ecol Prog Ser 43:1-10

del Giorgio PA, Cole JJ, Cimbleris A (1997) Respiration rates in bacteria exceed phytoplankton production in unproductive aquatic system. Nature 385:148-151

Doval MD, Alvarez-Salgado XA, Pérez FF (1997) Dissolved organic matter in a temperate embayment affected by coastal upwelling. Mar Ecol Prog Ser 157:21-37

Dugdale RC, Wallace JT (1960) Light and dark bottle experiments in Alaska. Limnol Oceanogr 5:230-231

Eppley RW (1989) New production: history, methods, problems. In: Berger WH, Smetacek VS, Wefer G (eds) Productivity of the ocean. Present and past. Wiley \& Sons, Chichester, p 85-97
Eppley RW, Peterson BJ (1979) Particulate organic matter flux and planktonic new production in the deep ocean. Nature $282: 677-680$

Estrada M (1984) Phytoplankton distribution and composition off the coast of Galicia (northwest of Spain). J Plankton Res 6:417-434

Fermín EG, Figueiras FG, Arbones B, Villarino ML (1996) Short-time evolution of a Gymnodinium catenatum population in the Ria de Vigo. J Phycol 32:21.2-221

Figueiras FG, Pazos Y (1991) Microplankton assemblages in three Rias Baixas (Vigo, Arosa and Muros, Spain) with subsurface chlorophyll maximum: their relationships to hydrography. Mar Ecol Prog Ser 76:219-233

Figueiras FG, Ríos AF (1993) Phytoplankton succession, red tides and the hydrographic regime in the Rías Bajas of Galicia. In: Smayda TJ, Shimizu Y (eds) Toxic phytoplankton blooms in the sea. Elsevier Science Publishers BV New York, p 239-244

Fraga F (1976) Fotosintesis en la Ría de Vigo. Invest Pesq 40:151-167

Fraga $F$ (1981) Upwelling off the Galician coast, Northwest Spain. In: Richards FA (ed) Coastal upwelling. American Geophysical Union, Washington, DC, p 176-182

Fraga S, Bakun A (1993) Global climate change and harmful algal blooms: the example of Gymnodinium catenatum on the Galician coast. In: Smayda TJ, Shimizu Y (eds) Toxic phytoplankton blooms in the sea. Elsevier Science Publishers BV, New York, p 59-65

Fraga S, Anderson DM, Bravo I, Reguera B, Steidinger KA, Yentsch CM (1988) Influence of upwelling relaxation on dinoflagellates and shellfish toxicity in Ria de Vigo, Spain. Estuar Coast Shelf Res 27:349-361

Fraga S, Bravo I, Reguera B (1993) Poleward surface current at the shelf break and blooms of Gymnodinium catenatum in Ria de Vigo (NW Spain). In: Smayda TJ, Shimizu Y (eds) Toxic phytoplankton blooms in the sea. Elsevier Science Publishers BV, New York, p 245-249

Geider RJ (1997) Photosynthesis or planktonic respiration? Nature 388:132-133

Griffith PC, Douglas DJ, Wainright SC (1990) Metabolic activity of size-fractionated microbial plankton in estuarine, nearshore, and continental shelf waters of Georgia. Mar Ecol Prog Ser 59:263-270

Hansen HP, Grasshoff K (1983) Automated chemical analysis. In: Grasshoff K, Ehrhardt M, Kremling K (eds) Methods of seawater analysis, 2nd edn. Verlag Chemie, Weinheim, p $347-379$

Hidy GM (1972) A view of recent air-sea interaction research. Bull Am Meteorol Soc 53:1083-1102

Hopkinson CS Jr (1985) Shallow-water benthic and pelagic metabolism: evidence of heterotrophy in the nearshore Georgia Bight. Mar Biol 87:19-32

Iriarte A, Daneri G, Garcia VMT, Purdie DA, Crawford DW (1991) Plankton community respiration and its relationship to chlorophyll a concentration in marine coastal waters. Oceanol Acta 14:379-388

Jensen LM, Sand-Jensen K, Marcher S. Hansen M (1990) Plankton community respiration along a nutrient gradient in a shallow Danish estuary. Mar Ecol Prog Ser 61:75-85

Kemp WM, Sampou PA, Garber J, Tuttle J, Boynton WR (1992) Seasonal depletion of oxygen from bottom waters of Chesapeake Bay: roles of benthic and planktonic respiration and physiological exchange processes. Mar Ecol Prog Ser 85:137-152

Kenney BE, Litaker W, Duke CS, Ramus J (1988) Community oxygen metabolism in a shallow tidal estuary. Estuar Coast Shelf Sci 27:33-43 
Kuparinen J (1987) Production and respiration of overall plankton and ultraplankton communities at the entrance to the Gulf of Finland in the Baltic Sea. Mar Biol 93:591-607

Langdon C (1993) The significance of respiration in production measurements based on oxygen. In: $\mathrm{Li}$ WKW, Maestrini SY (eds) Measurement of primary production from the molecular to the global scale, Vol 197. ICES Mar Sci Symp, Copenhagen, p 69-78

Laws EA (1991) Photosynthetic quotients, new production and net community production in the open ocean. DeepSea Res 38:143-167

Margalef R (1958) Temporal succession and spatial heterogeneity in phytoplankton. In: Buzzati-Traverso AA (ed) Perspectives in marine biology. University of California Press, Berkeley, CA, p 323-349

Minas HJ, Minas M, Packard TT (1986) Productivity in upwelling areas deduced from hydrographic and chemical fields. Limnol Oceanogr 31:1182-1206

Mouriño C. Fraga F (1985) Determinación de nitratos en agua de mar. Invest Pesq 49:81-96

Nogueira E, Pérez FF, Ríos AF (1997) Seasonal patterns and long-term trends in an estuarine upwelling ecosystem (Ria de Vigo, NW Spain). Estuar Coast Shelf Sci 44:285-300

Pazos Y, Figueiras FG, Alvarez-Salgado XA, Rosón G (1995) The control of succession in red tide species in the Ria de Arousa (NW Spain) by upwelling and stability. In: Lassus P, Arzul G, Erad E, Gentien P, Marcaillou C (eds) Harmful marine algal blooms. Technique et DocumentationLavoisier, Intercept Ltd, Paris, p 645-6.50

Pérez FF, Alvarez-Salgado XA, Rosón G, Ríos AF (1992) Carbonic-calcium system, nutrients and total organic nitrogen in continental runoff to the Galician Rias Baixas, W Spain. Oceanol Acta 15:595-602

Pérez FF, Ríos AF, King BA, Pollard R (1995) Decadal changes of the q-S relationship of the Eastern North Atlantic Central Water. Deep-Sea Res 42:1849-1864

Peterson BJ (1980) Aquatic primary productivity and the ${ }^{14} \mathrm{C}-\mathrm{CO}_{2}$ method: a history of the productivity problem. Annu Rev Ecol Syst 11:359-385

Pilskaln CH, Paduan JB, Chavez FP, Anderson RY, Berelson WM (1996) Carbon export and regeneration in the coastal upwelling system of Monterey Bay, central California. J Mar Res 54:1149-1178

Pitcher GC, Richardson AJ, Korrûbel JL (1996) The use of temperature in characterizing the mesoscale heterogeneity of phytoplankton in an embayment of the southern Benguela upwelling system. J Plankton Res 18:643-657

Pomeroy LR, Wiebe WJ, Deibel D, Thompson RJ, Rowe GT, Pakulski JD (1991) Bacterial responses to temperature and substrate concentration during the Newfoundland spring bloom. Mar Ecol Prog Ser 75:143-159

Pomeroy LR, Sheldon JE, Sheldon JR WM (1994) Changes in bacterial numbers and leucine assimilation during estimations of microbial respiratory rates in seawater by the precision Winkler method. Appl Environ Microbiol 60:328-332

Prego R (1993) General aspects of carbon biogeochemistry in the Ria de Vigo, northwestern Spain. Geochim Cosmochim Acta 57:2041-2052

Prego $R$ (1994) Nitrogen interchanges generated by biogeochemical processes in a Galician ria. Mar Chem 45: $167-176$

Prego R, Bao R (1997) Upwelling influence on the Galician. coast: silicate in shelf waters and underlying surface sediments. Cont Shelf Res 17:307-318
Quiñones RA, Platt T (1991) The relationship between the $\mathrm{f}$-ratio and the P:R ratio in the pelagic ecosystem. Limnol Oceanogr 36:211-213

Ríos AF, Nombela MA, Pérez FF, Rosón G, Fraga F (1992a) Calculation of runoff to an estuary: Ria de Vigo. Sci Mar 56:29-33

Ríos AF, Pérez FF, Fraga F (1992b) Water masses in the upper and middle North Atlantic Ocean east of Azores. DeepSea Res 39:645-658

Rosón G, Pérez FF, Alvarez-Salgado XA, Figueiras FG (1995) Variation of both thermohaline and chemical properties in an estuarine upwelling ecosystem: Ria de Arousa. I. Time evolution. Estuar Coast Shelf Sci 41:195-213

Sherr EB, Sherr BF (1996) Temporal offset in oceanic production and respiration processes implied by seasonal changes in atmospheric oxygen: the role of heterotrophic microbes. Aquat Microb Ecol 11:91-100

Smith EM, Kemp WM (1995) Seasonal and regional variations in plankton community production and respiration for Chesapeake Bay. Míar Ecol Prog Ser 116:217-231

Smith WO Jr (1977) The respiration of photosynthetic carbon in eutrophic areas of the ocean. J Mar Res 35:557-565

Strickland JDH, Parsons TR (1972) A practical handbook of seawater analysis, 2nd edn Bull Fish Res Board Can 167

Taylor CD, Howes BL (1994) Effect of sampling frequency on measurements of seasonal primary production and oxygen status in near-shore coastal ecosystems. Mar Ecol Prog Ser 108:193-203

Tenore KR and 18 co-authors (1982) Coastal upwelling in the Rias Bajas, NW Spain: contrasting the benthic regimes of the Rias de Arosa and de Muros. J Mar Res 40:700-772

Tilstone GH, Figueiras FG, Fraga F (1994) Upwelling-downwelling sequences in the generation of red tides in a coastal upwelling system. Mar Ecol Prog Ser 112:241-253

UNESCO (1981) Tenth report of the joint panel on oceanographic tables and standards. UNESCO Tech Pap Mar Sci 36

UNESCO (1986) Progress on oceanographic tables and standards 1983-1986: work recommendation of the UNESCO/SCOR/ICES/LAPSO joint panel. UNESCO Tech Pap Mar Sci 50

Vinogradov ME, Shushkina EA (1978) Some development patterns of plankton conmunities in the upwelling areas of the Pacific Ocean. Mar Biol 48:357-366

Walsh JJ (1991) Importance of continental margins in the marine biogeochemical cycling of carbon and nitrogen. Nature 350:53-55

Williams PJleB (1984) A review of measurements of respiration rates of marine plankton populations. In: Hobbie JE, Williams PЛeB (eds) Heterotrophic activity in the sea. Plenum Press, New York, p 357-389

Williams PJleB, Robertson JE (1991) Overall planktonic oxygen and carbon dioxide metabolisms: the problem of reconciling observations and calculations of photosynthetic quotients. J Plankton Res 13:159-169

Woodster WS, Bakun A, McLain DR (1976) The seasonal upwelling cycle along the eastern boundary of the North Atlantic. J Mar Res 34:131-141

Yentsch CS, Menzel DW (1963) A method for the determination of phytoplankton chlor ophyll and phaeophytin by fluorescence. Deep-Sea Res 10:221-231

Zdanowski MK, Figueiras FG (1997) Relationships between the abundance of bacteria and other biota and the hydrographic variability in the Ria de Vigo, Spain. Mar Ecol Prog Ser 147:257-267 